\title{
Transforming Research on Diversity and Firm Performance: A Dynamic Capabilities Perspective
}

\author{
Quinetta Roberson \\ Villanova University \\ Oscar Holmes IV \\ Rutgers, The State University of New Jersey \\ Jamie L. Perry \\ Cornell University
}

Final version published in Academy of Management Annals (2017), 11(1), 189-216 


\begin{abstract}
Despite a growing body of literature on diversity and firm performance, our review of research across fields, theoretical traditions, and levels of analysis suggests that the relationship is not a simple one. However, we attempt to integrate theory and research from macro and micro research domains into one perspective on the firm-level performance effects of diversity. We review the results of research on diversity and firm performance based on the level of analysis at which diversity was examined, highlighting what we know and do not know about this relationship, and why a new approach to research in this area is needed. To set a future research agenda, we introduce a dynamic capabilities framework for studying diversity and firm performance, identifying a subset of capabilities through which we would expect firms to extract benefit (or loss) from diversity and articulate the underlying mechanisms through which such effects are likely to occur. By putting forth this framework, our goal is to offer an integrative, process-based perspective for understanding value creation and capture as it pertains to diversity, and encouraging a more systemic approach to the study of diversity and firm performance.
\end{abstract}


Transforming Research on Diversity and Firm Performance: A Dynamic Capabilities Perspective

\section{Introduction}

Consistent with labor predictions, current workforces comprise employees with diverse abilities, cultural backgrounds, and work styles, with projections for even greater diversity (Mor Barak, 2013). Combined with rapidly changing and highly competitive environments, this trend has spurred a need for organizational leaders to understand the effects of demography on firm performance. An early study by Kennedy (1971) examined the effects of diversity and financial performance using 16 teams in a business simulation. Varying team composition based on cognitive complexity, or the level of information processing capacity, and college class, which was considered to be a proxy for age and maturity, the results showed effects of the former individual difference variable on average profit measures. Specifically, teams with greater than 50 percent abstract thinkers experienced a smaller profit loss (approximately three times lower) than teams with less than 50 percent abstract members. While several methodological issues limited the conclusions that could be drawn from Kennedy's (1971) study, it offered some preliminary results regarding the influence of different types of diversity on competitive performance and set the stage for future research on diversity and firm performance. Since then, an increasingly large body of literature has highlighted relationships between diversity at different levels of organizations and a variety of performance indicators, including margins (e.g., Boone \& Hendriks, 2009 ; Hartenian \& Gudmundson, 2000), returns (e.g., Li, Chu, Lam, \& Liao, 2011; Richard, 2000), and valuation (e.g., Roberson \& Park, 2007; Talke, Salomo, \& Rost, 2010).

While several reviews collectively offer a comprehensive summary of the diversityperformance literature (see Jackson, Joshi, \& Erhardt, 2003; Joshi, Liao, \& Roh, 2011; 
McMahon, 2010; Menz, 2012; Milliken \& Martins, 1996; Nielsen, 2010; Reis, Castillo, \& Dobon, 2007; van Knippenberg \& Schippers, 2007; Williams \& O’Reilly, 1998), the fragmented nature of the literature leaves the mechanisms underlying this relationship unaddressed. For example, although group-level research articulates the processes through which diversity affects performance outcomes, we have a limited understanding of how such processes and outcomes become manifested in the macro domain. Similarly, although top management team (TMT) research describes how member demographics influence strategic choice, little consideration has been given to the more micro-level processes through which such influence occurs. Firm-level diversity research assumes that cultural diversity is a unique and valuable resource that can be a source of competitive advantage for firms, yet few studies have considered the ways in which it might be developed or deployed to achieve such an advantage. Thus, the value of diversity in organizations remains a question.

Our overarching purpose is to integrate existing research across the human resource management, strategy, and group domains to advance an appreciation of the state of knowledge in the field of diversity and firm performance and suggest ways in which the field can move forward. However, as studies across domains have addressed different research questions, we present an organizing framework for understanding findings to date and set a future research agenda. Categorizing studies based on the level of analysis at which diversity was examined, we first review the results of research on diversity and firm performance. Based on this review, we highlight what we know and do not know about this relationship, and why a new approach to research in this area is needed. Given a number of unanswered questions about diversity's effects on firm-level outcomes, we propose a shift from the notion of diversity as an organizational resource that can lead to performance enhancements to a process-based perspective that 
considers a firm's capacity for deploying resources to adapt to environmental conditions and thus, for impacting organizational effectiveness. Specifically, we introduce a dynamic capabilities framework for understanding the value of diversity in firms and incorporating the creation and capture of value into the study of diversity and firm performance. We also identify a subset of capabilities through which we would expect firms to extract benefit (or loss) from diversity and articulate the underlying mechanisms through which such effects are likely to occur. We conclude by pinpointing opportunities (and challenges) associated with this more integrative approach to the study of diversity and firm performance, and offering a future research agenda.

Our overall intended contribution is to change the direction of future research to better inform the study of firm-level diversity effects. Given that dynamic capabilities reflect a firm's ability to leverage its resources to adapt to the changing business circumstances, our review considers the intersection of firms' internal and external environments. In addition, as dynamic capabilities take into account demography as a strategic resource and its configuration and integration into organizational routines as a source of value in organizations, our framework advances a focus on the processes through which diversity influences performance. Although prior research has incorporated contingency factors to resolve mixed findings regarding the relationship between diversity and firm performance, our framework offers an approach for investigating changes in this relationship as markets change. Specifically, by considering how value is created in organizations as well as firm-specific competencies generated from diversity, we attempt to examine diversity and firm performance from a complementary or fit perspective, establishing stronger links between diversity, process, and performance variables. Further, with a consideration of diversity effects on more localized firm outcomes, our review has the potential 
for enhancing the explanatory power and practical usefulness of future firm-level diversity research.

\section{A Review Of Diversity And Firm Performance Research}

\section{What We Know}

To review the literature on diversity and firm performance, we searched for articles using a coding scheme derived from the management, human resource, and strategy literatures. Given the absence of an established taxonomy at the firm level of analysis, we developed a list of diversity-related terms based on existing reviews of the literature (e.g., Certo, Lester, Dalton, \& Dalton, 2006; Joshi et al., 2011; Menz, 2012). Although a large body of work has examined the main and moderating effects of demographic attributes on organizational outcomes, most of them focus on unit-level performance. Our inquiry showed that although a variety of terms have been used interchangeably to refer to diversity, researchers have primarily relied upon five keywords to refer to the diversity as a contextual property of organizations-diversity, demography, composition, heterogeneity, and dissimilarity. Similarly, while performance has generally been used to capture the results of a firm's operations, researchers have also used other indicators of goal achievement, including value or valuation, productivity, and effectiveness. Accordingly, we used these terms to search for and identify empirical research that examines diversity as a structural property of organizations and the subsequent effects on firm-level performance.

Based on these criteria, we found 43 published articles exploring diversity in different forms and within different job categories. To organize this body of work, we categorize the studies based on the level of analysis at which diversity was examined and highlight the key 
findings (see Table 1). As shown in the table, prior work has primarily focused on the performance effects of diversity among boards of directors, TMTs, managers, and employees. We summarize the findings to date at each level, highlighting what we currently know about the relationship between diversity and performance, in the next section.

\section{Board diversity.}

Given that a firm's board of directors is a group of individuals elected to serve as its governing body, representing stockholders in decision-making on strategic issues and establishing management-related policy, studies at this level focus on how board composition influences its functioning and subsequently, firm performance outcomes. The research reviewed here examines the diversity of boards across various countries, including the United States (Carter et al., 2010; Carter et al., 2003; Erhardt et al., 2003), Canada (McIntyre et al., 2007), Spain (Campbell \& Mínguez-Vera, 2008, 2010), Denmark (Rose, 2007), Australia (Bonn, 2004), and New Zealand (Van der Walt et al., 2006). In addition, board compositional effects in firms across a variety of industries, including nonprofit sectors (Siciliano, 1996), have been examined.

In general, the findings of this body of work suggest that board diversity is related to firm performance. More specifically, as all of the studies conducted at this level of analysis have assessed the performance effects of gender diversity [for an exception, see McIntyre et al. (2007)], there is relatively consistent evidence that gender, in terms of both the presence and relative proportion of women on boards of directors, is positively related to firm performance. These studies also highlight the influence of gender on various performance indices, including profitability ratios and valuation measures, although the results are not uniform across such indices. For example, in a study of board diversity across YMCA organizations, Siciliano (1996) found gender diversity to be positively related to mission fulfillment, yet negatively related to 
level of donations. Similarly, Smith et al. (2006) uncovered differential effects of board gender composition and CEO gender on firm contribution and gross profit margins, respectively. Additionally, Carter et al. (2003) showed an association between the presence and percentage of women on boards and firm value, while a later study by Carter et al. (2010) revealed gender diversity on boards and board committees to be positively related to firm performance, but not to firm value. Though we might attribute these findings to differences in firm operations captured by dependent variables, it stands to reason that the diversity- performance relationship may also be shaped by other explanatory variables not measured in the studies.

Similar to the effects of gender diversity, the findings of the board diversity studies reviewed here reveal a positive relationship between racial diversity and firm performance (see Carter et al., 2003; Erhardt et al., 2003). However, when summarizing the collective findings across all dimensions of diversity within boards, the inferences that can be drawn are more complicated. For example, while Rose (2007) observed nonsignificant findings of board functional and national diversity on firm value, Siciliano (1996) uncovered positive effects of age and occupational diversity on firm performance. McIntyre et al. (2007) explored correlations between age and tenure diversity and firm value, and found an inverted U-shaped relationship, such that low and high levels of diversity on each dimension were associated with lower levels of performance while moderate levels of diversity were associated with higher performance. Accordingly, the researchers concluded that while a certain amount of age or tenure diversity on boards of directors is beneficial to firm performance, that performance benefit dwindles in firms with substantively homogeneous and heterogeneous boards. The findings of Van der Walt et al. (2006) further suggest that the relationship between board diversity and firm performance may be complex, given the moderating influence of strategic context. In particular, they found lower 
diversity in board composition to be associated with higher levels of performance, particularly in firms with high strategic complexity. Thus, taken together, we are left to speculate as to whether the firm performance effects of board diversity are dependent upon the type of diversity and/or strategic conditions under which such diversity operates.

Insert Table 1 Here

\section{TMT diversity.}

Several studies on diversity and firm performance have focused on the demography of TMTs, although conceptualizations of this work group have varied. For example, Finkelstein and Hambrick (1996) define TMT as all corporate officers who also serve as board members, while other researchers have included those with the title of vice president or above (e.g., Carpenter, 2002; Goll et al., 2001; Keck, 1997; Li-Qun et al., 2005; Murray, 1989; Olson et al., 2006;

Pegels et al., 2000; Ren \& Wang, 2011; Richard \& Shelor, 2002). Yet, other researchers allowed firm CEOs to define their TMT and identify who should be included in the study (Boone \& Hendriks, 2009; Buyl et al., 2011; Simons et al., 1999; West \& Schwenk, 1996). Two notable exceptions include Roberson and Park (2007), who conceptualized a firm's TMT to be represented by the 25 top- paid officers in a firm, which captures significant variability in demographic data reported to the Securities Exchange Commission (SEC), and Kilduff et al. (2000), who used a sample of experienced managers participating in a team business simulation as part of an executive education program.

The findings of research at the TMT level of analysis suggest that diversity is positively related to firm performance. Some studies show direct correlations between member diversity 
and firm performance along a variety of dimensions, including functional background, age, tenure, and education diversity (e.g., Certo et al., 2006; Goll et al., 2001; Kilduff et al., 2000; LiQun et al., 2005). However, as research also provides evidence of direct relationships with TMT age and occupational diversity, yet simultaneously reveals negative impacts of education and career experience diversity on firm performance (Li-Qun et al., 2005), the diversity-performance relationship may not be that straightforward, but instead may be driven by internal contingencies, such as team characteristics and firm strategic context.

Only two studies reviewed here examined the effects of TMT demographic diversity, such as gender and racial composition, on firm performance. Ren and Wang (2011) explored the performance effects of female participation on TMTs and found gender diversity to be positively related to firm value, especially when the human and social capital of female members is high. Roberson and Park (2007) considered the effects of top management racial diversity on a variety of indicators of firm performance and found evidence of a curvilinear U-shaped relationship, such that firm value declined with increases up to an inflection point of approximately 22 percent representation by racial minorities, beyond which additional increases in diversity were associated with improved economic value. While strong conclusions cannot be drawn from these two studies, the results suggest that the performance effects of TMT demographic diversity may be dependent on the degree to which such differences between members are leveraged to enhance team and/or firm effectiveness.

One study by Boone and Hendriks (2009) considered potential effects of TMT diversity in terms of personality and value differences on firm performance. Specifically, they hypothesize that because such differences may give rise to interpersonal conflict that reduces team effectiveness, firm performance will be negatively impacted. As expected, the results showed 
TMT locus of control diversity to be inversely related to firm performance, but only under conditions of high decision-making decentralization within the TMT. Consequently, this study highlights the potentially detrimental consequences of deeper-level composition variables in TMTs, exacerbating effects of internal contingencies, and need to study the influence of team mechanisms on the diversity-performance relationship.

Most studies of TMT diversity and firm performance have focused on member differences that are indicative of the team's pool of task-related resources. Researchers have primarily investigated the performance effects of TMT age, education, functional background, and tenure diversity, which are theorized to capture differences in member knowledge, perspectives, and experiences that are relevant for the team's functioning. Interestingly, rather than establish a straightforward relationship between diversity and firm performance, the findings of this subset of studies highlight the importance of external contingencies in determining the nature of the relationship. For example, Murray (1989) found positive associations between TMT occupational and tenure diversity and firm performance to be especially pronounced in the oil industry, whereas Pegels et al. (2000) uncovered negative relationships between TMT functional and educational diversity and performance in the airline industry, based on the degree to which a firm differed from its competitive action group. Likewise, the results of Keck (1997) showed industry-dependent effects, such that functional heterogeneity was positively related to firm performance in turbulent contexts, while the directionality of the tenure diversity-performance relationship varied in turbulent versus stable contexts. Richard and Shelor (2002) discovered a positive relationship between TMT age diversity and firm performance, although the form of the relationship also differed across performance indicators and environmental contingencies. Specifically, age diversity was found 
to have both positive linear and curvilinear relationships with sales growth, which are strengthened under conditions of environmental complexity, innovation and decentralization, and a positive linear relationship with return on assets, which is enhanced in decentralized contexts. Other studies that have taken a contingency approach to understanding the effects of TMT diversity on performance have emphasized more on localized contextual factors, such as firm leadership or team characteristics. For instance, Boone and Hendriks (2009) examined the relationship between TMT functional diversity and firm performance, and found a positive association when team information-processing mechanisms, such as decision-making decentralization and information exchange, were high. Similarly, Buyl et al. (2011) discovered a positive impact of TMT functional diversity on firm performance, which became more pronounced as the CEO had more shared experiences with team members. As this moderating effect was mediated by the interaction of functional diversity and information exchange, they conclude that the performance benefits of diversity are realized under conditions that facilitate knowledge management within TMTs. The importance of information exchange in the relationship between TMT diversity and performance is further highlighted by research showing the mediating role of strategic choice variables. Consistent with the findings of the studies reviewed earlier, Olson et al. (2006) found functional diversity to be positively related to firm performance; however, this relationship was mediated by two growth decisions - internal innovation and mergers and acquisitions (M\&A) activity. Simons et al. (1999) explored the performance effects of TMT educational and perceived environmental uncertainty (PEU) diversity, or the variability in member perceptions of uncertainty in the external environment, which is postulated to have a key influence on strategic decision-making. Consistent with a contingency perspective, both dimensions of diversity were found to interact with debate to 
influence firm performance, such that margins were higher for firms with more diverse TMTs and that engaged in more debate. However, as these results were partially mediated by decision comprehensiveness, or the degree to which teams consider multiple approaches, decision criteria, and courses of action, Simons et al. point to the need for research to consider the roles of process variables in the effects of diversity on firm performance.

\section{Managerial diversity.}

Another subset of the articles on diversity and firm performance has focused on the managerial level of analysis. However, the conclusions that can be drawn regarding the effects of manager diversity on firm performance are limited by a generalized conceptualization of manager, which has included officials at various levels. For example, studies have included data for supervisors and other lower-level managers, for department heads and other middle-level managers, and for vice-presidents and other chief executive officers (Andrevski et al., 2014; Dwyer et al., 2003; Richard et al., 2004). Other research has included members of firm oversight bodies, such as corporate boards of directors (e.g., Shrader et al., 1997) or centrally located administrators and school superintendents (Pitts \& Jarry, 2007).

While all of the studies conducted at this level have considered the effects of manager gender and racial diversity on firm performance, their results vary based on contextual factors and the measurement of performance. For example, Shrader et al. (1997) compared the performance effects of gender diversity among boards, TMTs, and managers, and discovered only manager diversity to be significantly and positively related to firm profitability. Dwyer et al. (2003) also found a positive link between manager gender diversity and employee productivity; however, the effect was limited to firms with a strong growth orientation or clan culture. At the same time, they found a concurrent negative association between manager gender diversity and 
return on equity in firms with a strong adhocracy culture. These findings are consistent with those of Richard et al. (2004), which show the relationship between manager gender diversity and productivity to interact with a firm's risk posture, such that average levels of diversity are associated with higher performance than are low and high levels of diversity in high-risk-taking firms, suggesting that the effects of diversity among managers may be conditioned on a firm's strategic and cultural orientation. This conclusion is further buoyed by the results of studies examining performance effects of manager racial diversity, which have been shown to be dependent on firms' competitive intensity and innovativeness (Andrevski et al., 2014; Richard et al., 2004).

\section{Employee diversity.}

Research exploring effects of employee diversity has focused on the demographic composition of workforces, although there is substantive variability in the types of samples used. For example, while some studies have used archival data reporting the demographic composition of firms' labor forces (e.g., Frink et al., 2003; Herring, 2009; Leonard et al., 2004; Li et al., 2011; Richard et al., 2007), others have surveyed firm officers regarding the representation of different groups in their workforces (Richard, 2000; Richard et al., 2003; Richard et al., 2006). Researchers have also relied on self-reported demographic information provided by employee samples (e.g., Gonzalez \& DeNisi, 2009; Hartenian \& Gudmundson, 2000; Kunze et al., 2011).

Although research on workforce diversity and firm performance has primarily focused on the effects of employee gender and racial diversity, the results have been equivocal. Some studies have found direct positive and negative effects of diversity on performance (e.g., Hartenian \& Gudmundson, 2000; Herring, 2009; Pitts \& Jarry, 2007), dependent upon how diversity and performance were assessed. Other studies have revealed that the form of the 
diversity-performance relationship is based on the specific demographic composition of workforces or the communities in which firms are located (e.g., Frink et al., 2003; Leonard et al., 2004). Still, the findings of most diversity-performance research conducted at this level of analysis draw attention to the range of intervening variables through which this relationship operates. For example, Richard (2000), his colleagues (Richard et al., 2003,2006), and others (Li et al., 2011) have shown organizational factors, such as business strategy, span of control, and life cycle, to impact the nature of the diversity- performance relationship regardless of the dimensions of diversity studied. The moderating influences of extra-organizational factors, such as environmental stability and munificence, in addition to national culture, have been highlighted as well (Li et al., 2011; Richard et al., 2007). In contrast, based on an assumption that the benefits of diversity may be enabled in certain internal environments, researchers have examined the extent to which employee shared beliefs and values - specifically, diversity-related climates, or perceptions of how supportive firm practices are of workforce diversity-alter its impact on firm performance (Gonzalez \& DeNisi, 2009; Kunze et al., 2011). The results of these studies show the effects of employee gender and racial diversity to be stronger under supportive diversity climate conditions (Gonzalez \& DeNisi, 2009), and for the performance effects of age diversity to operate through discrimination climate perceptions and collective affective commitment (Kunze et al., 2011). Thus, as noted in several of these studies, the aforementioned results substantiate an association between workforce diversity and performance, but only under certain circumstances, highlighting ambiguities and complexities of the relationship.

\section{Summary.}

As shown by our review, we have several insights into the relationship between diversity and firm performance. First, we know that diversity at various levels of the firm is related to 
performance. Focused on the composition of organizational work groups, including boards of directors, TMTs, managers, and employees, researchers have explored the potential impact of diversity on organizational effectiveness. More importantly, as these studies provide evidence of associations between work group demography and performance outcomes, the findings suggest that diversity has a firm-level impact, specifically on a firm's bottom line. Second, we know that diversity's impact is through its influence on work group functioning. While a large literature on diversity in groups and teams has highlighted the processes through which it affects cognitive, affective, and behavioral consequences (see Milliken \& Martins, 1996; van Knippenberg \& Schippers, 2007; Williams \& O'Reilly, 1998), the studies reviewed in this article extend such effects to the firm level of analysis and suggest mechanisms through which the diversityperformance relationship may occur. Through an examination of the mediating influences of sensemaking and strategic choice processes, we identified potential process gains and losses that may stem from diversity and subsequently affect firm performance. Third, we know that the effects of diversity on firm performance are dependent upon features of the context in which it resides. With interest in the third-variable effects of a broad range of team, organizational, and extraorganizational factors (Joshi \& Roh, 2009), the studies reviewed here identify boundary conditions of the diversity-performance relationship. By highlighting internal and external circumstances that alter the strength and/or direction of the relationship, the findings reflect complexities in the operation of diversity and offer a contingency approach to understanding its effects in organizations. 


\section{What We Do Not Know}

While research to date provides useful tests of theory and evidence of a relationship between diversity and firm performance, it also draws attention to a number of inconsistencies that give rise to some unanswered questions. As shown in Table 2, studies across levels of analysis seem to lack coherence in terms of the dimensions of diversity examined, indicators of performance, theoretical and mediating mechanisms through which diversity operates, and contexts that facilitate (or hinder) diversity's effects. Such variations make it challenging to reconcile findings across levels and draw conclusions about the nature of the diversityperformance relationship, thus constraining continued development of this literature. In the next section, we discuss these susceptibilities and the need for a more systematic approach to the study of firm-level diversity effects.

\section{What types of diversity are related to firm performance?}

In most studies of diversity and firm performance, researchers have focused on individual characteristics that may create distinctions between people in organizations. Conceptualized as individual differences relative to others in organizational work groups along certain dimensions, diversity is treated as a compositional characteristic of boards, TMTs, mangers, and workforces. Accordingly, researchers have assessed the proportional representation of different categories within such groups or the proportional amount of a given attribute held by members of those groups, and the subsequent effects on firm performance outcomes.

Although the performance effects of a broad array of diversity dimensions have been examined, some distinctions between studies at different levels of analysis are evident. For example, while TMT research has explored the influence of knowledge- based dimensions of 
diversity, such as education and functional background, research at other levels has primarily focused on gender and racial differences between members. This bifurcated approach to the study of diversity is consistent with the larger literature, which has separated diversity characteristics according to their level of task orientation, or the degree to which each captures the knowledge, skills, and abilities relevant to the performance of cognitive tasks in organizations (Pelled, 1996; Simons et al., 1999). Alternatively, diversity research distinguishes between observable or surface-level attributes, such as gender and race, and less salient or deeplevel attributes, such as functional background and education (Harrison, Price, \& Bell, 1998; Jackson, May, \& Whitney, 1995). This grouping of diversity dimensions is meaningful, as research has shown them to be differentially related to outcomes. Specifically, surface-level characteristics have been found to be associated with outcomes associated with intergroup relations, such as group attachment and social integration, while deep-level characteristics tend to evoke responses related to information processing, including communication and task conflict (Jackson et al., 2003; Milliken \& Martins, 1996; van Knippenberg \& Schippers, 2007; Williams \& O'Reilly, 1998). For that reason, these differential outcomes also have ramifications for our understanding of the relationship between diversity and firm performance.

Given the attribute approach used in current research, we know which diversity dimensions are related to performance, but have limited insight into how different types of diversity are related to performance. Because the collective findings of research reviewed here suggest that all dimensions of diversity can, in principle, be both positively and negatively associated with firm performance, the mechanisms cannot be assumed on the basis of the diversity characteristic studied. Further, as studies of the effects of surface- versus deep-level diversity characteristics have developed in separate research traditions, we are less able to 
forecast when they will occur. Consequently, a more integrative theoretical framework is needed to enhance our ability to explain the diversity- performance relationship as well as the predictive power of firm-level diversity research.

Insert Table 2 Here

\section{How does diversity relate to different types of firm performance?}

Similar to the conceptualization of diversity, firm-level research has captured performance effects in a variety of ways. With over 30 indicators of performance included in the studies we reviewed, the findings offer comprehensive evidence of a relationship between diversity and firm performance. However, because much of the research uses single or unrelated indicators (Richard, Devinney, Yip, \& Johnson, 2009), our ability to identify how diversity influences organizational effectiveness is constrained. Some differentiation in categories of performance outcomes studied across levels of analysis is also apparent. For example, board diversity research seems to focus on stock measures, which reflect investor perceptions of a firm's value as well as its ability to generate future cash flows. These include measures such as Tobin's Q and market-to-book values, which compare the market versus replacement value of a firm's assets, although these measures may be manipulated by the level of intangible assets. In contrast, TMT research overwhelmingly uses return measures, which signal a firm's ability to generate earnings from a given portfolio (i.e., sales, assets, equity, and investments).

Accordingly, this subset of studies examine the effects of TMT diversity on firm profitability, or efficiency in utilizing production assets to generate earnings, and liquidity, or ability to meet financial obligations based on cash flows generated from operations (Hamann, Schiemann, 
Bellora, \& Guenther, 2013). Among the studies exploring effects of manager and employee diversity on firm performance, there is greater variability in performance outcomes used. Similar to stock and return indices, measures of market access or growth, such as variations in sales/revenues and market share, and which reflect changes in firm size, are utilized (Weinzimmer, Nystrom, \& Freeman, 1998).

With the use of stock, return, and growth measures as dependent variables, most of the research reviewed here has focused on the relationship between diversity and firm financial performance. However, as noted by Venkatraman and Ramanujam (1986), financial indicators represent "the narrowest conception of business performance" (p. 803), as they merely signal the achievement of a firm's economic goals. While a focus on economic success is a rational objective, there are several assumptions in the use of such indicators of performance, including that the actions of boards, TMTs, managers, and/or employees directly impact financial outcomes and are the primary driver of such outcomes. Yet, because financials can be impacted by an array of external and internal factors, such as economic conditions and accounting policies, a more localized view of performance may more accurately capture value creation (or diminution) resulting from a firm's internal actions.

\section{What are the mechanisms through which the effects of diversity occur?}

The research reviewed here draws upon a wide range of theories, although it seems that the specific theories used to develop conceptual foundations are dependent on the level of analysis at which diversity is studied. For example, to articulate the mechanisms through which board diversity influences firm performance, researchers have primarily drawn upon social psychological and value-in-diversity theories. Social psychological theories, such as social identity (Tajfel, 1978) and self-categorization (Turner, 1985), propose that because individuals' 
self-definitions are shaped by their group memberships, they are motivated to enhance their selfconcept by seeking a positively valued distinctiveness for those groups. Accordingly, they engage in social comparisons to differentiate between their in-groups and relevant out-groups, which accentuate similarities among individuals sharing group memberships and differences among those belonging to different identity groups. Such comparisons subsequently have both a positive and a negative influence on intergroup relations and subsequently, firm performance.

Board diversity research has also drawn upon a number of theories and perspectives that consider the unique resources that diversity provides. For example, the "value-in-diversity" hypothesis (Cox, Lobel, \& McLeod, 1991) suggests that because diversity broadens the knowledge, perspectives, and other cognitive resources to which groups have access, its benefit is through enhanced problem-solving and decision-making performance. This is also consistent with an information elaboration perspective that suggests that diverse groups are exposed to a variety of informational resources, which give rise to minority viewpoints and task conflict and subsequently motivate the consideration of more creative and better quality alternatives and solutions (Williams \& O'Reilly, 1998). Relatedly, resource dependence theory (Pfeffer \& Salancik, 1978) suggests that because the principal function of boards is to provide firms with resources (including information), network ties, and other forms of support that allow them to address issues of environmental uncertainty and gain legitimacy in external markets, board diversity may enhance a firm's fit with the external environment and subsequently, performance.

Studies examining the performance effects of diversity at lower levels have also drawn upon the aforementioned theoretical perspectives, although they primarily rely on a distinctive conceptual perspective. For example, TMT diversity research has mainly drawn upon upper echelons theory (Hambrick \& Mason, 1984), which suggests that because strategic choices made 
by senior-level managers are driven by their cognitive and behavioral characteristics, diverse TMTs have a greater capacity for generating and evaluating firms' strategic alternatives, and thus for influencing firm performance. In contrast, employee diversity research is largely rooted in the resource-based view (RBV) of the firm (Barney, 1991), which posits that the specific demography of an organization can facilitate competencies that develop from complex social relationships and cannot be perfectly duplicated by competitors (Barney, 1991), creating performance differences across firms. Notably, the few studies conducted on managerial diversity have drawn upon several of the theories and perspectives discussed here.

Although a variety of theoretical explanations have been offered to elucidate the connection between diversity and firm performance, only a handful of studies have tested the processes underlying the relationship. Consistent with the theoretical perspectives used, such research highlights the importance of strategic choice, information exchange, and competitive activity for eliciting the advantages and disadvantages of diversity, and its subsequent impact on performance (Andrevski et al., 2014; Buyl et al., 2011; Olson et al., 2006; Simons et al., 1999). Still, our understanding of the casual relationship between diversity and firm performance is limited. We can cognize diversity as both a resource and a source of operational resources, but have little knowledge of its value to firms. We have numerous justifications for the diversityperformance relationship, but lack a unified framework that incorporates effects between levels of analysis. For these reasons, a coherent approach for studying the social and operational dynamics through which diversity's effects on firm performance occur is needed.

\section{In what contexts does diversity enable firm performance?}

Despite some patterns in theories used, diversity characteristics studied, and performance outcomes measured across levels of analysis, quite the opposite is true for moderators to the 
diversity-performance relationship. Of the studies we reviewed, approximately 23 distinct quantitative and qualitative contextual factors were tested. While such variables can be classified based on endogeneity (i.e., organizational vs. extra-organizational) and level (i.e., team vs. organization), varied findings regarding the nature and form of their effects obscure our understanding of the situational settings in which the effects of diversity are amplified or diminished. For example, while Richard et al. $(2003,2004)$ find the relationship between racial diversity and firm performance to be moderated by innovation, the form of the relationship differs across levels of analysis. Specifically, low and high levels of managerial racial diversity are associated with higher performance than are moderate levels of managerial racial diversity in firms with an innovation strategy (Richard et al., 2004), whereas employee racial diversity enhances performance in banks pursuing an innovation strategy and reduce performance in those with a lower degree of innovation (Richard et al., 2003). As both studies were conducted on samples of banks, we can extrapolate that features of the management versus employee job categories, the former of which "set broad policies, exercise overall responsibility for the execution of these policies, and direct individual departments or special phases of a firm's operations" (Richard et al., 2004: 259), or other contextual factors, enable the outcomes of diversity differently, thus altering the diversity-performance relationship. Because studies in this area have primarily adopted a contingency perspective to the diversity-performance relationship, examining how contextual factors alter its direction and/ or strength, we have insight into how specific factors change its effects. However, we have less insight into the conditions that enable diversity to yield its effects. Thus, an approach to the study of diversity and firm performance that considers environmental fit, or the complementarity between firm's diversity resources and the contexts in which they are embedded, is needed. 


\section{Moving from "What" To "How"}

Early diversity research suggests that the value of diverse workforces is driven by the potential effects on organizational processes (Cox \& Blake, 1991). Specifically, diversity is viewed as a resource that translates into a competitive advantage for firms through a greater capacity for creativity, problem-solving, and responding to changes in the external environment. In addition, through reputation and an enhanced ability to understand the needs and demands of diverse consumer markets, diversity is posited to improve a firm's resource acquisition and marketing capabilities. Given the role of capabilities in translating diversity into firm performance, we believe that such a perspective may be key to advancing future research in this area. Specifically, we speculate that a dynamic capabilities approach may offer an integrative framework for studying and understanding firm-level effects of diversity.

Dynamic capability theory describes competencies that influence a firm's resource base in ways that it is able to respond to changes in market demand and enhance operational effectiveness (Ambrosini \& Bowman, 2009; Helfat et al., 2007; Teece \& Pisano, 1994). By distinguishing between resources, or inputs into a firm's production processes, and capabilities, or a firm's capacity for deploying resources to adapt to evolving market conditions (Helfat \& Peteraf, 2003), the theory extends the RBV of a firm to focus on organizational choices and routines for achieving sustainable competitive advantage in dynamic business environments. For example, competencies that provide firms with an ability to transform its products and services, methods and scale of production, and markets served are described as dynamic capabilities (Winter, 2003). It is this conceptualization of capabilities such as firm-specific processes to adapt and create new resource positions, and subsequently facilitate value creation and capture, which 
bridges the conversion gap between resource inputs and performance outputs (Dutta, Narasimhan, \& Rajiv, 2005).

Because dynamic capabilities refer to a firm's capacity for action (Teece \& Pisano, 1994), the theory considers the emergent properties of organizations - specifically, the capacity for extracting economic benefit from their resource bases. While organizational routines may develop from a variety of resource types, dynamic capabilities are assumed to emerge from the social complexity of human capital resources, as they are collaborative activities for obtaining, combining, and deploying a firm's human assets to support business goals and respond to environmental changes (Eisenhardt \& Martin, 2000; Helfat et al., 2007). Distinguished from operational capabilities, which encompass the day-to-day activities for generating and delivering products and services, dynamic capabilities enable firms to transform these processes to take advantage of market opportunities and achieve competitive advantage (Winter, 2003). As such, the value of dynamic capabilities is not in the control of such resources, but in their functionality. Capabilities are produced through knowledge- based activities, which allow a firm to realize value through the accumulation, combination, and exploitation of resources (Sirmon, Hitt, \& Ireland, 2007). While a range of managerial and organizational processes may influence firm competitiveness, research suggests that those activities with the potential for leading to competitive advantage primarily fall within three core areas: integration, learning, and transformation (see Teece \& Pisano, 1994; Teece, Pisano, Shuen, 1997). Integration represents the coordination of assets and competences in ways that develop firm-specific capabilities (Teece et al., 1997). As certain competences may be complementary, integration activities are those that organize firm assets and processes both within and between business units to take advantage of such interdependencies. In effect, such coordination of resources and their allocation to key 
business processes facilitates the development of organizational routines, which enhance a firm's capacity for dealing with environmental change and subsequently, its performance (Eisenhardt \& Martin, 2000; Helfat \& Peteraf, 2003). Learning represents a capacity for acquiring new knowledge and leveraging it to create new forms of strategic advantage (Easterby-Smith \& Prieto, 2008). It involves the examination of current practice to improve upon business processes as well as the identification of new opportunities for integration and coordination. Such learning activities integrate a firm's knowledge base with its asset position to streamline existing business processes and cultivate new organizational routines, which strengthen a firm's strategic readiness (Teece et al., 1997). Transformation represents a capacity for sensing environmental changes and reconfiguring resources ahead of industry rivals (Teece et al., 1997). It involves gathering or anticipating information about consumer needs, competitor actions, and other market trends, and using such knowledge to make decisions about strategic direction. Consequently, transforming activities create value by enabling firm-specific capabilities for analysis and agility that allow continuous adaptation to ever-changing market conditions (Eisenhardt \& Martin, 2000).

Consistent with the value-in-diversity hypothesis (Cox et al., 1991), dynamic capabilities research suggests that the integration of individual and group competences within organizations may serve as a source of competitive advantage for firms. However, we extend this hypothesis by articulating how the coordination of resources and knowledge into organizational routines may influence firm competitiveness. It is through this activity-based understanding of how firm assets can be configured to influence strategic positioning that dynamic capabilities theory can itself be used to integrate current conceptual explanations for the relationship between diversity at different levels of the firm and firm performance. For example, by accounting for shifts in market demands and conditions, it extends the more static, RBVs of diversity and firm 
performance. Specifically, as resources alone are considered to be insufficient to sustain competitive advantages in rapidly changing and unpredictable operating conditions, a dynamic capabilities perspective considers how firms' internal environments may be configured and reconfigured to match their external environments to sustain performance gains. By encapsulating collective processes through which organizations create and alter operating routines to generate performance benefits (Zollo \& Winter, 2002), a dynamic capability approach extrapolates the underlying mechanisms articulated by group-level diversity theories [e.g., social psychological, information processing and decision-making, Categorization Elaboration Model (CEM) (van Knippenberg, De Dreu, and Homan 2004)] to the firm-level of analysis. Thus, a dynamic capabilities framework allows the integration of theoretical perspectives on diversity and firm performance while offering a unique explanation of the processes through such effects.

\section{A Capabilities Model of Diversity and Firm Performance}

Although many types of capabilities may influence firm performance, we focus on those expected to be shaped by diversity. Using Cox and Blake's (1991) arguments for how diversity might contribute "net-added value to organizational processes" (p. 46) as a starting point, we identified a subset of capabilities through which we would expect diversity to affect firm performance. Specifically, we focus our discussion on the following: market access, research and development (R\&D), efficiency, knowledge management, alliancing/brokerage, and system flexibility (see Figure 1). Next we discuss each capability and how different types of diversity may influence each and subsequently, indicators of organizational effectiveness. 


\section{Market Access}

Diversity in firms may influence market access, or a firm's capability for entering and competing in specific markets (Gelos, Sahay, \& Sandleris, 2011). As a primary functional activity, marketing can serve as a source of competitive advantage by adding value to firms' goods or services (Porter, 1985). Through branding and differentiating products and services from those of rivals, marketing capabilities also allow firms to meet competitive demands (Gelos et al., 2011). As such, this capability for understanding and delivering on consumer needs may facilitate the development of new customer and client relationships and trust within established markets, thereby increasing the likelihood that consumers are willing to purchase goods and services and for higher prices from specific firms.

Given cultural diversity in customer and client markets, Thomas and Ely (1996) propose that matching such diversity in workforces provides firms with an ability to reach and understand a broader range of consumers. They posit that because such segments of the market have specialized wants and needs, having their perspectives represented and understood within firm workforces provides access to, and legitimacy with, those segments. Thus, as cultural backgrounds are considered assets for enhancing a firm's capability for entering and competing in specific markets, we would expect diversity in surface-level characteristics to be associated with their capability for market access. Specifically, given that differences in values, beliefs, and attitudes within a firm may enable a more comprehensive understanding of consumer markets (including traditionally underserved groups), diversity along these dimensions may improve its capability for connecting to a broader clientele, thus expanding its market share and improving market indicators of performance. 


\section{Insert Figure 1 Here}

Extant research highlights the potential for market access to emerge as a capability from firm-level diversity. For example, Leonard et al. (2004) found retail sales in Hispanic and Asian communities to be higher in stores with employees who culturally identified themselves with the surrounding communities in which they were located, particularly in areas where clients had limited English proficiency. Consistent with Thomas and Ely's (1996) access-and- legitimacy perspective, these results suggest that identification with the racioethnic background of the community may have provided firms with a greater association with that community and thus, access to potential customers. Further, because such identification may have afforded stores an enhanced ability to understand and meet the needs of the community, it follows that the market access gained translated into increased store performance. Another study by Siciliano (1996) also provides some evidence of market access as a diversity capability, as the results showed age diversity to be positively related to the level of donations, which was considered to be an indicator of community or public support. Interestingly, however, as the results showed gender diversity to be negatively related to donations, Siciliano speculated that "women may not have access to needed economic, social and political resources" (1996:1319), suggesting that diversity may also relate to a firm's capability for alliancing, which is discussed later.

\section{Research and Development}

R\&D is the capability for engaging in activities to discover and create new and/or better products, services, or operational procedures (Dutta et al., 2005; Krasnikov \& Jayachandran, 2008). It involves the application of knowledge to generate product- market innovations, such as 
new product design and service enhancements, or process innovations, such as the adoption of new equipment or technologies, which enhance performance or cost attributes of existing products or services (Krasnikov \& Jayachandran, 2008). Regardless of the type of innovation, an R\&D capability can aid in the expansion of product and service offerings in ways that are valued by consumers and therefore can command premium pricing and/or increased margins. Research also suggests that an $R \& D$ capability may be regenerative in that organizations with this capability may be more likely to accrue complementary knowledge and skills, which enhances its resource position (Cohen \& Levinthal, 1990; Helfat, 1997). Accordingly, the capability for R\&D has long been considered a potential source of sustainable competitive advantage (see Capon, Farley, \& Hoenig, 1990; Roberts, 2001).

On basis of the value-in-diversity hypothesis, Cox and Blake (1991) argue that diverse perspectives in organizations should provide firms with a greater capacity for creativity and innovation. Some empirical evidence provides support for this argument, highlighting a relationship between certain forms of diversity in groups-specifically, informational differences - and innovative performance (see Milliken \& Martins, 1996; van Knippenberg \& Schippers, 2007). Research has shown firms with more diverse knowledge and technology resource positions to be more innovative and able to exploit such resources in ways that foster R\&D (Garcia-Vega, 2006; Quintana-Garcia \& Benavides-Velasco, 2008). For these reasons, we would expect deep-level diversity to be associated with their capability for R\&D. As differences in knowledge, expertise, and experience may provide a firm with unique information to discover areas of expansion and improvement for its portfolio of products and services, diversity along these deep-level dimensions may improve its capability for taking advantage of market 
opportunities, thereby increasing the likelihood of above-average returns in terms of market indicators of performance.

A study by Olson et al. (2006), which examines strategic choice as a mediator in the relationship between TMT diversity and firm performance, offers some evidence of R\&D as a capability resulting from diversity. Consistent with our propositions, the findings showed surface-level diversity to be negatively related to strategic choice, measured as innovation inputs or R\&D intensity, and deep-level diversity to be positively related to strategic choice. As the findings also revealed the relationship between TMT functional diversity and firm performance to be fully mediated by strategic choice, they collectively suggest that such diversity may facilitate the development of product and process innovations that create value and subsequently enhance firm performance. Thus, a firm's capability for using its diversity resources, particularly at higher levels, to facilitate growth through $\mathrm{R} \& \mathrm{D}$ may be critical to its realization of the value of diversity.

\section{Knowledge Management}

Knowledge management is defined as the process of capturing, organizing, and optimizing the deployment of a firm's intellectual assets (Hedlund, 1994). Differentiated from R\&D, knowledge management involves the effective coordination of knowledge-related resources rather than the application to operational processes. It is through the structuring and integration of people, procedures, and technologies that existing knowledge is transferred and new knowledge is generated, which facilitates advancement toward organizational objectives (Scarbrough \& Swan, 2003). Research suggests that the value in this capability is in opportunities for cooperation and mutual learning, which relate positively to other capabilities, 
such as innovation and responsiveness (Tsai, 2001). These combined capabilities, in turn, allow firms to take competitive action against rivals and achieve improved relative performance (Decarolis \& Deeds, 1999; Miller, Fern, \& Cardinal, 2007).

Although the value-in-diversity hypothesis suggests that diversity should enhance a firm's capability for R\&D, sociological theories propose an opposing effect on its capability for knowledge management. Studies have shown the distribution of resources in a group to be positively related to conflict and negatively associated to process variables, such as communication and cooperation (see Milliken \& Martins, 1996; Williams \& O’Reilly, 1998). Accordingly, researchers have attributed such process losses to the emergence of power and status hierarchies, which provoke greater stratification and competition within work units (see van Knippenberg et al., 2004). Following this logic, we would expect both surface- and deeplevel diversity to be associated with a firm's capability for knowledge management. With diversity along surface-level dimensions, work group members may diverge on their motivation, interests, and perceived value of the group's identity. However, with diversity along deep-level dimensions, differences in the relative standing or influence of members may emerge.

Nevertheless, because resource differences within work groups may create tensions that reduce interdependencies and coordination, diversity may lower the productivity of knowledge assets.

Two of the TMT studies reviewed earlier emphasize knowledge management as a diversity capability. Buyl et al. (2011) examined the effects of CEO characteristics and shared experience with TMT members on the relationship between TMT functional diversity and firm performance, and found the association to be stronger under conditions of high tenure overlap. More importantly, the results showed the impact to be through distributed knowledge exchange and integration within the team. Similarly, another study revealed interactive effects of TMT 
deep-level diversity characteristics and debate on decision comprehensiveness, which in turn, positively impacted firm performance (Simons et al., 1999). Taken together, the results of these studies suggest that diversity must be effectively drawn out and integrated into knowledge management processes if a firm is to derive value from it.

\section{Efficiency}

Operational capabilities represent a firm's capacity for converting inputs into outputs with the goals of enhancing process objectives, such as quality and reliability (Miller \& Roth, 1994). Focused on the coordination of resources and execution of routines (Helfat \& Peteraf, 2003), such capabilities incorporate a firm's day-to-day operations in the production and delivery of products and services. Research suggests that the value in operational capabilities is in the resultant technical efficiency, which allows firms to address market demand uncertainty and/or compete more effectively in terms of cost and quality (Teece, 2007). Thus, through the application of knowledge-based resources to generate product and process improvements, a firm's capability for operational efficiency enables its ability to meet or exceed consumer needs, thereby increasing its likelihood for competitive success in the marketplace (see Tan, Kannan, \& Narasimhan, 2007).

Similar to our above argument regarding the link between diversity and a capability for knowledge management, we would expect diversity to reduce communication and cooperation within firms, thus potentially reducing work group functioning and hence, firm performance. However, research also suggests the potential for competing effects, as knowledge differences have been shown to influence efficiency measures of team performance (see Ancona \& Caldwell, 1992; Bantel \& Jackson; 1989; Hauptman \& Hirji, 1996; Keller, 2001). Specifically, 
the findings of such research reveal positive effects of team functional diversity on schedule and budget performance, driven by communication external to the team. Following this logic, we would expect deep-level diversity in firms to be positively related to their capability for operational efficiency, as such differences may provide access to more and unique knowledgerelated resources, which may enhance technical quality. Consequently, greater operational efficiency may improve a firm's schedule and budget performance, which may translate into higher operational performance overall.

Siciliano (1996) explored the relationship between board diversity and operational efficiency, represented by the ratio of total revenues to total expenses for each of 240 YMCA organizations. Although the correlations between different types of diversity and efficiency were nonsignificant, these results may provide some insight into where the operational value of diversity resides. Considering that operational capabilities represent a firm's capacity for converting inputs into outputs, it follows that diversity in such conversion processes would impact its capability for efficiency. At the same, we would expect that diversity among board members would be less related to efficiency given that boards have responsibility for firm governance rather than its day-to-day operations. Further, while Siciliano (1996) used revenueto-expenses ratio to capture the efficiency with which organizations controlled expenses and managed their staff, the metric may not have adequately captured their technical efficiency in terms of their coordination of resources. Accordingly, additional research is needed to explore the value-creating (or value-diminishing) potential of diversity on firms' capability for efficiency.

\section{Alliancing}


As strategic alliances are voluntary agreements between organizations to exchange and share resources (Gulati, 1998), the ability to form and effectively manage multiple alliances is considered to be an important capability in competitive markets (Ireland, Hitt, \& Vaidyanath, 2002). As alliances provide firms with access to different types of information and resources located in the external environment, the value of this capability is in the exploitation of available competences to create new resources and interdependencies that lead to innovative forms of competitive advantage (Teece et al., 1997). Research findings highlight the impact of alliancing on innovation, in terms of new product development and ventures, which have subsequently been shown to influence value creation in investor markets (see Rothaermel \& Deeds, 2006). Accordingly, the capability for alliancing is considered to drive a firm's ability to operate in rapidly changing environments and thus, serves as a potential source of sustainable competitive advantage (Ireland et al., 2002).

While Cox and Blake (1991) argue for the effects of diversity on resource acquisition in terms of a firm's ability to attract the best human resources, the underlying logic also applies to a firm's capability for alliancing. Social network research has shown diversity in individuals' network connections to facilitate access to different types of knowledge and information, which subsequently influences knowledge diffusion and transfer (Reagans \& McEvily, 2003; Reagans \& Zuckerman, 2001). More accurately referred to as network range, or the proportion of network ties that cross organizational and institutional boundaries (Burt, 1992), such boundary spanning is considered to enhance the capacity for resource exchange and organizational learning (Reagans \& Zuckerman, 2008). Thus, as differences in network ties may provide access to a wider array of and more unique resources, we would expect surface-level diversity in firms to be associated with their capability for alliancing. Further, as the transfer of information, both within 
and outside organizations, is associated with improved performance (Burt, 1992), a firm's

alliancing capability may influence its return on knowledge assets and subsequently, performance in investor markets.

In addition to considering the influence of TMT diversity on firms' capability for R\&D, Olson et al. (2006) examined its effects on alliancing. Operationalizing strategic choice as the number of M\&A in which a firm engages, they found TMT functional diversity to be positively associated, and TMT age diversity to be negatively associated, with strategic choice, which mediated the diversity-firm performance relationship. These results suggest that diversity, especially within leadership, may provide firms with an ability to effectively form and manage partnerships, thereby enhancing their capacity for competing in dynamic markets. Thus, as we speculate above, the performance effects of diversity in firms may also occur through an increased capability for alliancing with other entities.

\section{Strategic Flexibility}

Strategic flexibility refers to a firm's capability for sensing and responding to environmental changes (Eisenhardt, 1989). It captures a capacity for adaptability, such that firms can devise ways of dealing with potential and/or unexpected market threats and challenges, as well as a concurrent capacity for speed, such that firms can adapt quickly to competitive changes in the market. It also implies a capacity for dealing with complexity given that markets can be characterized by interorganizational connections, network alliances, and path dependencies (Zaheer \& Zaheer, 1997). Because strategic flexibility involves both environmental scanning and response, research suggests that this capability creates value for firms through the use and reconfiguration of knowledge assets to be responsive to competitive signals and market forces 
(Teece et al., 1997). This value is supported by empirical evidence demonstrating a link between strategic flexibility and firm performance (see Zaheer \& Zaheer, 1997).

Cox and Blake (1991) posit that diversity enhances organizational flexibility.

Specifically, they argue that because diversity engenders less system standardization and greater system agility, organizations will be able to respond to changes in their external environmental more quickly and at lower costs. Such effects are likely to occur through access to diverse and nonredundant sources of information (Burt, 1992), which provides firms with greater awareness of environmental trends. As research has shown that such environmental knowledge enhances a firm's capacity for reacting to market variations (Eisenhardt, 1989; Zaheer \& Zaheer, 1997), we would expect deep-level diversity in firms to be associated with their capability for strategic flexibility. While the specific source of such diversity may vary (e.g., industry experience, network ties, functional background), we conjecture that such strategic flexibility will improve firms' abilities to generate cash flows, increase market value, and enhance other investor indicators of performance.

Andrevski et al. (2014) investigated the mediating role of competitive intensity, or a firm's ability to identify and exploit opportunities for generating competitive actions, in the relationship between managerial diversity and performance. Given that the results showed racial diversity among managers to be positively related to the initiation and variety of competitive actions, which were subsequently related to firm performance, especially in high-growth environments, we might conclude that diversity enhances a firm's capability for strategic flexibility. Because such flexibility encompasses environmental scanning and responding to competitive changes in the market, the findings suggest that integrating diversity into such activities may create value for firms through a greater ability to respond to market forces. 
Additional research is needed, however, to explore and understand strategic flexibility as a dynamic capability that translates diversity into firm performance.

\section{Organizational Effectiveness}

Organizational effectiveness refers to a firm's performance outcomes most directly associated with its strategies, tactical objectives, and stakeholder interests (Richard et al., 2009). Broader than measures of financial performance and economic valuation, such measures capture value created (or reduced) by a firm's capabilities and its subsequent impact on firm competitiveness. While firms have divergent strategic motivations that give rise to different measurement needs, research suggests that organizational effectiveness can primarily be indicated by three categories of indicators: market, operational, and stakeholder.

Market indicators are those outcomes that reflect a firm's performance among customers, clients, or others who use its products or services. Operationalized via perceptual or behavioral measures, market indicators signal consumer attitudes, intentions, or purchase/consumption of a product or service (Gupta \& Zeithaml, 2006). Such indicators may include customer satisfaction, customer loyalty, return intentions, and customer yield (e.g., contacts to close). Market indicators may also include metrics that are reflective of a firm's market reach, or capacity to expand or diversify its target markets, such as new product/service development (in terms of number and rate), product/ service variety, and customer diversity.

Operation indicators refer to those measures that quantify the achievement of a firm's goals and objectives within its value chain activities (Combs, Crook, \& Shook, 2005). Such measures indicate the efficiency or effectiveness of a firm's operational processes, which directly influence its overall performance (Hamann et al., 2013). For example, productivity measures 
such as cycle or delivery time, service processing time, lead time, utilization, effort reduction, budget performance, and quality may provide insight into how well a firm is using its diversity resources. Similarly, more qualitative measures, such as learning and strategic human resource effectiveness (Huselid, Jackson, \& Schuler, 1997), may capture how effectively a firm is managing such resources.

Stakeholder indicators are those outcomes that reflect a firm's performance among other groups that are directly impacted by a firm's actions and have an interest in its success. For example, as investors put capital into firms with the intent of realizing a return on their investment, metrics such as investor satisfaction, investment intentions, and donations or funds raised, may reflect a firm's capacity for externally generating resources. Similarly, as firm performance is typically dependent upon economic transactions with other entities, value creation may be assessed via measures of partnership effectiveness, such as number of strategic alliances, supplier performance, and total earned value. Community engagement metrics, which include participation and local reputation, may also be useful for gauging the effects of diversity on organizational effectiveness.

\section{Directions for Future Research}

The proposed model and its underlying assumptions introduce a new approach to research on diversity and firm performance. Extending current perspectives of diversity as a resource or compilation of resources for organizational action, we offer a process-based perspective for understanding its deployment in ways that impact firm effectiveness. We argue for moving beyond the examination of statistical relationships between diversity and firm financial performance to focus on how firms operate and the integration of diversity into such 
operational processes. By considering the potential impact of diversity on firms' value-driven activities, we consider diversity both as a resource in organizations and as firms' abilities to extract economic benefit from this resource. It should be noted, however, that our proposed list of diversity capabilities is not intended to be exhaustive, but instead intended to stimulate thinking about how value is created in organizations based on existing theory and research about the effects of diversity. Thus, future studies of diversity and firm performance should consider how diversity resources might be configured to develop capabilities for addressing competitive demands. While the capabilities explored may be more generalized (e.g., R\&D capability) or firm-specific (e.g., patent development or commercialization), we believe that this approach can be useful for gaining greater insight into how diversity-related processes influence firm-level outcomes.

While our model does not specify the level at which diversity resides, future research may make predictions regarding the effects of different types of diversity based on the firm capabilities of interest. For example, as the principal function of boards of directors is to enable access to distinctive resources that can be deployed for environmental scanning and reacting to environmental uncertainty (Pfeffer \& Salancik, 1978), both surface- and deep- level diversity may be may be particularly influential in the development of firm capabilities. However, their effects on specific capabilities may deviate, as surface characteristics may facilitate a firm's capability for alliancing given more stratified links to the external environment, while deep characteristics may enhance its capability for strategic flexibility, or the ability to respond to changes in that environment. Similarly, as decisions regarding how to combine resources drive capability development (Teece et al., 1997), managerial actions to innovate new business processes may be enabled by deep-level diversity, while surface characteristics may give rise to 
coordination issues and other process losses, thereby diminishing knowledge management. As suggested by these examples, the particular capabilities shaped by diversity may depend on the types of diversity, and the resultant effects may be either positive or negative. Accordingly, future research should explore diversity-capability relationships at different levels to capture the additive effects of diversity and better account for net value creation in organizations.

While our model offers guidance for distinguishing between different types of firm performance, it poses some advantages and challenges for assessing these effects. Given that capabilities are more directly impacted by firm activities, our framework offers a more localized view of performance. However, given variability in organizational routines and outputs, the operationalization of diversity-related capabilities may differ across firms. For example, R\&D capability may be indicated by return on R\&D investment in one firm and patent yield in another. Likewise, efficiency may be measured as the rate of improvement in cycle time (i.e., speed of production) or rate of improvement in yield (i.e., quality of production). Considering the range of metrics to represent performance along capability dimensions, we recommend the use of multiple indicators in the interest of both content validity and reliability. In addition to reflecting measurable process factors in organizations, such an approach would allow greater comparisons across studies at different levels of analysis as well as improve the explanatory power of such variables on firm financial performance.

Although much of the dynamic capabilities literature explores how firms' asset positions can lead to competitive advantages, some researchers recommend also giving consideration to strategic liabilities to fully understand firms' net performance (Arend, 2004, 2008). Strategic liabilities are resources that damage and/or destroy a firm's ability to produce rents (Arend, 2004), and therefore detract from its overall performance. It is important to note that such 
liabilities are not inherently destructive, but provide less value to a firm than it does to its rivals given variable applicability across firms (Sirmon, Hitt, Arregle, \& Campbell, 2010). Strategic liabilities are also economically inconvertible and incommutable, such that costs to convert the liability into a strategic asset outweigh expected economic gains to a firm and those costs cannot be transferred to other parties, respectively (Arend, 2004; Powell, 2001). Consequently, such liabilities may not only provide greater value to rivals, but also reduce a firm's competitiveness through inefficiencies, an increased likelihood of attack by rivals, and/or an inability to take advantage of market opportunities (Sirmon et al., 2010).

To fully examine the net firm performance effects of diversity, future research should consider its value- creating and value-reducing potential. For example, as suggested in the previous section, increased surface- and deep-level diversity in a firm's R\&D unit may enhance its capability for new product development while slowing down the product development process. Thus, research is needed to capture the aggregate impact of diversity on firm performance through different firm capabilities. Similarly, as strategic liabilities may emerge as a by-product of previous capabilities (Arend, 2004), research that examines changes in a firm's ability to realize the value in diversity may provide insight into the conditions that move diversity from a capability to a strategic liability. For instance, while a firm may hire for specific competencies (e.g., language skills or cultural knowledge) to gain market access and/or address an underserved need in the marketplace, rivals may subsequently develop similar capabilities, thus reducing the firm's product/service demand and market share. Alternatively, if the firm does not have a climate to facilitate the management and inclusion of such diversity, other potential liabilities in the form of retention issues, damage to its employment brand, or even lawsuits may result. Accordingly, research attention to strategic liabilities, and more specifically, the balance 
between capabilities and liabilities resulting from diversity, may be important for advancing the diversity-firm performance literature.

There are important implications for future research that go beyond testing our proposed model. Specifically, as a fundamental assumption of dynamic capabilities theory is that the value of capabilities increases in dynamic, rather than in stable, environments (Zollo \& Winter, 2002), capability models of diversity and firm performance should incorporate market or industry characteristics. This is not to suggest the exploration of contextual variables as boundary conditions to the relationships proposed here. Instead, our recommendation is for future research to consider how resources should be configured to develop and deploy capabilities to drive value creation in particular contexts. While the utility of dynamic capabilities is generalizable, research suggests that complexity and/or uncertainty increase their value (Eisenhardt \& Martin, 2000). Accordingly, accounting for the relationships between different types of diversity and capabilities across dimensions of dynamism and unpredictability may provide insight into environmental fit (Teece et al., 1997)—specifically, how diversity influences capabilities that facilitate greater adaption in changing environments.

\section{CONCLUSION}

Despite a growing body of literature on diversity and firm performance, our review of research across fields, theoretical traditions, and levels of analysis suggests that the relationship is not a simple one. However, we endeavored to integrate theory and research across both macro and micro research domains into one perspective on the firm-level performance effects of diversity. We believe this integration represents the major contribution of our article as it allows us to see points of convergence and divergence, identify unanswered questions about the diversity-performance relationship, speculate mechanisms underlying this relationship, and direct 
the field toward an alternative approach to research in this area. It should be noted that our review is not intended to criticize existing research given that such studies have been effective for providing a performance-based perspective on diversity. Instead, we hope to encourage an integrative, process-based perspective to understand value creation and capture as it pertains to diversity and firm-level outcomes. We believe that this should be the next iteration of research in this area if we are to advance an understanding of the operation of diversity within and between firms and to make prescriptions for how to leverage diversity resources to impact organizational performance. 


\section{References}

Ambrosini, V., \& Bowman, C. 2009. What are dynamic capabilities and are they a useful construct in strategic management. International Journal of Management Reviews, 11: $29-49$.

Ancona, D. G., \& Caldwell, D. F. 1992. Demography and design: Predictors of new product team performance. Organization Science, 3: 321-341.

Andrevski, G., Richard, O. C., Shaw, J. D., \& Ferrier, W. J. 2014. Racial diversity and firm performance: The mediating role of competitive intensity. Journal of Management, 40: 820-844.

Arend, R. J. 2004. The definition of strategic liabilities, and their impact on firm performance. Journal of Management Studies, 41: 1003-1027.

Arend, R. J. 2008. Differences in RBV strategic factors and the need to consider opposing factors in turnaround outcomes. Managerial and Decision Economics, 29: 337-355.

Bantel, K. A., \& Jackson, S. E. 1989. Top management and innovations in banking: Does the composition of the top team make a difference? Strategic Management Journal, 10: 107124.

Barney, J. 1991. Firm resources and sustained competitive advantage. Journal of Management, 17: 99-120.

Bonn, I. 2004. Board structure and firm performance: Evidence from Australia. Journal of Management and Organization, 10: 14-24.

Boone, C., \& Hendriks, W. 2009. Top management team diversity and firm performance: Moderators of functional-background and locus-of-control diversity. Management Science, 55: 165-180. 
Burt, R. S. 1992. Structural holes: The social structure of competition. Cambridge, MA: Harvard University Press.

Buyl, T., Boone, C., Hendriks, W., \& Matthyssens, P. 2011. Top management team functional diversity and firm performance: The moderating role of CEO characteristics. Journal of Management, 48: 151-177.

Campbell, K., \& Mínguez-Vera, A. 2008. Gender diversity in the boardroom and firm financial performance. Journal of Business Ethics, 83: 435-451.

Campbell, K., \& Mínguez-Vera, A. 2010. Female board appointments and firm valuation: Short and long-term effects. Journal of Management and Governance, 14:37-59.

Capon, N., Farley, J. U., \& Hoenig, S. 1990. Determinants of financial performance: A metaanalysis. Management Science, 36: 1143-1159.

Carpenter, M. A. 2002. The implications of strategy and social context for the relationship between top management team heterogeneity and firm performance. Strategic Management Journal, 23: 275-284.

Carter, D. A., D’Souza, F., Simkins, B. J., \& Simpson, W. G. 2010. The gender and ethnic diversity of US boards and board committees and firm financial performance. Corporate Governance, 18: 396-414.

Carter, D. A., Simkins, B. J., \& Simpson, W. G. 2003. Corporate governance, board diversity, and firm value. Financial Review, 38: 33-54.

Certo, S. T., Lester, R. H., Dalton, C. M., \& Dalton, D. R. 2006. Top management teams, strategy and financial performance: A meta-analytic examination. Journal of Management Studies, 43: 813-839. 
Cohen, W. M., \& Levinthal, D. A. 1990. Absorptive capacity: A new perspective on learning and innovation. Administrative Science Quarterly, 35:128-152.

Combs, J. G., Crook, T. R., \& Shook, C. L. 2005. The dimensionality of organizational performance and its implications for strategic management research. In D. J. Ketchen (Ed.), Research methodology in strategy and management, vol. 2: 259-286. Amsterdam, The Netherlands: Elsevier.

Cox, T., Jr., \& Blake, S. 1991. Managing cultural diversity: Implications for organizational competitiveness. Academy of Management Executive, 5: 45-56.

Cox, T. H., Lobel, S., \& McLeod, P. 1991. Effects of ethnic group cultural differences on cooperative and competitive behavior on a group task. Academy of Management Journal, 34: 827-847.

Decarolis, D. M., \& Deeds, D. 1999. The impact of stocks and flows of organizational knowledge on firm performance: An empirical investigation of the biotechnology industry. Strategic Management Journal, 20: 953-968.

Dutta, S., Narasimhan, O., \& Rajiv, S. 2005. Research notes and commentaries and measuring methodology and empirical capabilities: Application. Strategic Management Journal, 26: $277-285$.

Dwyer, S., Richard, O. C., \& Chadwick, K. 2003. Gender diversity in management and firm performance: The influence of growth orientation and organizational culture. Journal of Business Research, 56:1009-1019.

Easterby-Smith, M., \& Prieto, I. M. 2008. Dynamic capabilities and knowledge management: An integrative role for learning? British Journal of Management, 19: 235-249. 
Eisenhardt, 1.1989. Making fast strategic decisions in high-velocity environments. Academy of Management Journal, 32: 543-576.

Eisenhardt, K. M., \& Martin, J. A. 2000. Dynamic capabilities: What are they? Strategic Management Journal, 21: 1105-1121.

Erhardt, N. L., Werbel, J. D., \& Shrader, C. B. 2003. Board of director diversity and firm financial performance. Corporate Governance, 11:102-111.

Finkelstein, S., \& Hambrick, D. C. 1996. Strategic leadership top executives and their effects on organizations. St. Paul, MN: West Publishing.

Frink, D. D., Robinson, R. K., Reithel, B., Arthur, M. M., Ammeter, A. P., Ferris, G. R., Kplan, D.M., Morrisette, H. S. 2003. Gender demography and organization performance. Group and Organization Management, 28: 127-147.

Garcia-Vega, M. 2006. Does technological diversification promote innovation? An empirical analysis for European firms. Research Policy, 35: 230-246.

Gelos, R. G., Sahay, R., \& Sandleris, G. 2011. Sovereign borrowing by developing countries: What determines market access? Journal of International Economics, 83: 243-254.

Goll, I., Sambharya, R. B., \& Tucci, L. A. (2001). Top management team composition, corporate ideology, and firm performance. Management International Review, 41: 109-129.

Gonzalez, J. A., \& DeNisi, A. S. 2009. Cross-level effects of demography and diversity climate on organizational attachment and firm effectiveness. Journal of Organizational Behavior, 30: 21-40.

Gulati, R. 1998. Alliances and networks. Strategic Management Journal, 19: 293-317.

Gupta, S., \& Zeithaml, V. 2006. Customer metrics and their impact on financial performance. Marketing Science, 25: 718-739. 
Hamann, P. M., Schiemann, F., Bellora, L., \& Guenther, T. W. 2013. Exploring the dimensions of organizational performance: A construct validity study. Organizational Research Methods, 16: 67-87.

Hambrick, D. C., \& Mason, P. A. 1984. Upper echelons: The organization as a reflection of its top managers. Academy of Management Review, 9: 193-206.

Harrison, D. A., Price, K. H., \& Bell, M. P. 1998. Beyond relational demography: Time and the effects of surface-and deep-level diversity on work group cohesion. Academy of Management Journal, 41: 96-107.

Hartenian, L. S., \& Gudmundson, D. E. 2000. Cultural diversity in small business: Implications for firm performance. Journal of Developmental Entrepreneurship, 5: 209-219.

Hauptman, O., \& Hirji, K. K. 1996. The influence of process concurrency on project outcomes in product development: An empirical study of cross functional teams. IEEE Transactions on Engineering Management, 43: 153-164.

Hedlund, G. 1994. A model of knowledge management and the N-form corporation. Strategic Management Journal, 15: 73-90.

Helfat, C. E. 1997. Know-how and asset complementarity and dynamic capability accumulation: The case of R\&D. Strategic Management Journal, 18: 339-360.

Helfat, C. E., Finkelstein, S., Mitchell, W., Peteraf, M., Singh, H., Teece, D., \& Winter, S. G. 2007. Dynamic capabilities: Understanding strategic change in organizations. Malden, MA: Blackwell.

Helfat, C. E., \& Peteraf, M. A. 2003. The dynamic resource- based view: Capability lifecycles. Strategic Management Journal, 24: 997-1010. 
Herring, C. 2009. Does diversity pay?: Race, gender, and the business case for diversity. American Sociological Review, 74: 208-224.

Huselid, M. A., Jackson, S. E., \& Schuler, R. S. 1997. Technical and strategic human resource effectiveness as determinants of firm performance. Academy of Management Journal, 40: 171-188.

Ireland, R. D., Hitt, M. A., \& Vaidyanath, D. 2002. Alliance management as a source of competitive advantage. Journal of Management, 28: 413-446.

Jackson, S. E., Joshi, A., \& Erhardt, N. L. 2003. Recent research on team and organizational diversity: SWOT analysis and implications. Journal of Management, 29: 801-830.

Jackson, S. E., May, K. A., \& Whitney, K. 1995. Understanding the dynamics of diversity in decision making teams. In R. A. Guzzo \& E. Salas (Eds.), Team decision making effectiveness in organizations: 204-261. San Francisco, CA: Jossey-Bass.

Joshi, A., Liao, H., \& Roh, H. 2011. Bridging domains in workplace demography research: A review and conceptualization. Journal of Management, 37: 521-552.

Joshi, A., \& Roh, H. 2009. The role of context in work team diversity research: A meta-analytic review. Academy of Management Journal, 52: 599-627.

Keck, S. L. 1997. Top management team structure: Differential effects by environmental context. Organization Science, 8: 143-156.

Keller, R. T. 2001. Cross-functional project groups in research and new product development: Diversity, communications, job stress, and outcomes. Academy of Management Journal, 44: 547-555. 
Kennedy, J. L. 1971. The system approach: A preliminary exploratory study of the relation between team composition and financial performance in business games. Journal of Applied Psychology, 55: 46-49.

Kilduff, M., Angelmar, R., \& Mehra, A. 2000. Top management-team diversity and firm performance: Examining the role of cognitions. Organization Science, 11: 21-34.

Krasnikov, A., \& Jayachandran, S. 2008. The relative impact of marketing, research-anddevelopment, and operations capabilities on firm performance. Journal of Marketing, 72: $1-11$.

Kunze, F., Boehm, S. A., \& Bruch, H. 2011. Age diversity, age discrimination climate and performance consequences - A cross organizational study. Journal of Organizational Behavior, 32: 264-290.

Leonard, J. S., Levine, D. I., \& Joshi, A. 2004. Do birds of a feather shop together? The effects on performance of employees' similarity with one another and with customers. Journal of Organizational Behavior, 25: 731-754.

Li, J., Chu, C. W. L., Lam, K. C. K., \& Liao, S. 2011. Age diversity and firm performance in an emerging economy: Implications for cross-cultural human resource management. Human Resource Management, 50: 247-270.

Li-Qun, W., Chung-Ming, L., \& Young, M. N., \& Wang, Z. 2005. The impact of top management team demography on firm performance in China. Asian Business and Management, 4: 227-250.

McIntyre, M. L., Murphy, S. A., \& Mitchell, P. 2007. The top team: examining board composition and firm performance. Corporate Governance, 7: 547. 
McMahon, A. M. 2010. Does workplace diversity matter? A survey of empirical studies on diversity and firm performance, 2000-09. Journal of Diversity Management, 5: 37-48.

Menz, M. 2012. Functional top management team members: A review, synthesis, and research agenda. Journal of Management, 38: 45-80.

Miller, D. J., Fern, M. J., \& Cardinal, L. B. 2007. The use of knowledge for technological innovation within diversified firms. Academy of Management Journal, 50: 307-325.

Miller, J. G., \& Roth, A. V. 1994. A taxonomy of manufacturing strategies. Management Science, 40: 285-304.

Milliken, F. J., \& Martins, L. L. 1996. Searching for common threads: Understanding the multiple effects of diversity in organizational groups. Academy of Management Review, 21: $402-433$.

Mor Barak, M. E. 2013. Managing diversity: Toward a globally inclusive workplace (3rd ed.). Thousand Oaks, CA: Sage Publications.

Murray, A. I. 1989. Top management group heterogeneity and firm performance. Strategic Management Journal, 10: 125.

Nielsen, S. 2010. Top management team diversity: A review of theories and methodologies. International Journal of Management Reviews, 12: 301-316.

Olson, B. J., Parayitam, S., \& Twigg, N. W. 2006. Mediating role of strategic choice between top management team diversity and firm performance: Upper echelons theory revisited. Journal of Business and Management, 12: 111-126.

Pegels, C. C., Song, Y. I., \& Baik, Y. 2000. Management heterogeneity, competitive interaction groups, and firm performance. Strategic Management Journal, 21:911. 
Pelled, L. 1996. Demographic diversity, conflict, and work group outcomes: An intervening process theory. Organization Science, 7: 615-631.

Pfeffer, J., \& Salancik, G. R. 1978. The external control of organizations: A resource dependence perspective. New York: Harper \& Row.

Pitts, D., \& Jarry, E. 2007. Ethnic diversity and organizational performance: Assessing diversity effects at the managerial and street levels. International Public Management Journal, 10: 233-254.

Porter, M. E. 1985. Competitive advantage: Creating and sustaining competitive advantage. New York: Free Press.

Powell, T. C. 2001. Competitive advantage: Logical and philosophical considerations. Strategic Management Journal, 22: 875-888.

Quintana-Garcia, C., \& Benavides-Velasco, C. A. 2008. Innovative competence, exploration and exploitation: The influence of technological diversification. Research Policy, 37: 492507.

Reagans, R., \& McEvily, B. 2003. Network structure and knowledge transfer: The effects of cohesion and range. Administrative Science Quarterly, 48: 240-267.

Reagans, R., \&Zuckerman, E. W. 2001. Networks, diversity and productivity: The social capital of corporate R\&D teams. Organization Science, 12: 502-517.

Reagans, R., \& Zuckerman, E. 2008. Why knowledge does not equal power: The network redundancy trade-off. Industrial and Corporate Change, 17: 903-944.

Reis, C. R., Castillo, M. A. S., \& Dobon, S. R. 2007. Diversity and business performance: 50 years of research. Service Business, 1: 257-274. 
Ren, T., \& Wang, Z. 2011. Female participation in TMT and firm performance: Evidence from Chinese private enterprises. Nankai Business Review International, 2: 140-157.

Richard, O. C. 2000. Racial diversity, business strategy, and firm performance: A resource-based view. Academy of Management Journal, 43:164-177.

Richard, O. C., Barnett, T., Dwyer, S., \& Chadwick, K. 2004. Cultural diversity in management, firm performance, and the moderating role of entrepreneurial orientation dimensions. Academy of Management Journal, 47: 255-266.

Richard, P. J., Devinney, T. M., Yip, G. S., \& Johnson, G. 2009. Measuring organizational performance: Towards methodological best practice. Journal of Management, 35: 718804.

Richard, O. C., Ford, D., \& Ismail, K. 2006. Exploring the performance effects of visible attribute diversity: The moderating role of span of control and organizational life cycle. International Journal of Human Resource Management, 17: 2091-2109.

Richard, O. C., McMillan, A., Chadwick, K., \& Dwyer, S. 2003. Employing an innovation strategy in racially diverse workforces: Effects on firm performance. Group and Organization Management, 28:107-126.

Richard, O. C., Murthi, B., \& Ismail, K. 2007. The impact of racial diversity on intermediate and long-term performance: The moderating role of environmental context. Strategic Management Journal, 28: 12131233.

Richard, O. C., \& Shelor, R. M. 2002. Linking top management team age heterogeneity to firm performance: Juxtaposing two mid-range theories. International Journal of Human Resource Management, 13: 958-974. 
Roberson, Q. M., \& Park, H. J. 2007. Examining the link between diversity and firm performance: The effects of diversity reputation and leader racial diversity. Group and Organization Management, 32: 548-568.

Roberts, P. W. 2001. Innovation and firm-level persistent profitability: A Schumpeterian framework. Managerial and Decision Economics, 22: 239-250.

Rose, C. 2007. Does female board representation influence firm performance? The Danish evidence. Corporate Governance, 15: 404.

Rothaermel, F. T., \& Deeds, D. L. 2006. Alliance type, alliance experience and alliance management capability in high-technology ventures. Journal of Business Venturing, 21: 429-460.

Scarbrough, H., \& Swan, J. 2003. Discourses of knowledge management and the learning organization: Their production and consumption. In M. Easterby-Smith \& M. A. Lyles (Eds.), Handbook of organizational learning and knowledge management: 495-512. Oxford, UK: Blackwell Publishing.

Shrader, C. B., Blackburn, V. B., \& Iles, P. 1997. Women in management and firm financial performance: An exploratory study. Journal of Managerial Issues, 9: 355-372.

Siciliano, J. I. 1996. The relationship of board member diversity to organizational performance. Journal of Business Ethics, 15: 1313-1320.

Simons, T., Pelled, L. H., \& Smith, K. A. 1999. Making use of difference: Diversity, debate, and decision comprehensiveness in top management teams. Academy of Management Journal, 42: 662-673. 
Sirmon, D. G., \& Hitt, M. A., Arregle, J.-L., \& Campbell, J. T. 2010. The dynamic interplay of capability strengths and weaknesses: Investigating the bases of temporary competitive advantage. Strategic Management Journal, 31: 1386-1409.

Sirmon, D., Hitt, M., \& Ireland, D. 2007. Managing firm resources in dynamic environments to create value: Looking inside the black box. Academy of Management Review, 32: 273292.

Smith, N., Smith, V., \& Verner, M. 2006. Do women in top management affect firm performance? A panel study of 2,500 Danish firms. International Journal of Productivity and Performance Management, 55:569-593.

Tajfel, H. 1978. Differentiation between social groups. London: Academic Press.

Talke, K., Salomo, S., \& Rost, K. 2010. How top management team diversity affects innovativeness and performance via the strategic choice to focus on innovation fields. Research Policy, 39: 907-918.

Tan, K. C., Kannan, V. R., \& Narasimhan, R. 2007. The impact of operations capability on firm performance. International Journal of Production Research, 45:5135-5156.

Teece, D. J. 2007. Explicating dynamic capabilities: The nature and microfoundations of (sustainable) enterprise performance. Strategic Management Journal, 28: 1319-1350.

Teece, D. J., \& Pisano, G. 1994. The dynamic capabilities of firms: An Introduction. Industrial and Corporate Change, 3: 537-556.

Teece, D. J., Pisano, G., \& Shuen, A. 1997. Dynamic capabilities and strategic management. Strategic Management Journal, 18: 509-533.

Thomas, D. A., \& Ely, R. J. 1996. Making differences matter: A new paradigm for managing diversity. Harvard Business Review, 74: 79-90. 
Tsai, W. 2001. Knowledge transfer in intraorganizational networks: Effects of network position and absorptive capacity on business unit innovation and performance. Academy of Management Journal, 44: 996-1004.

Turner, J. C. 1985. Social categorization and the self-concept: A social cognitive theory of group behavior. In E. E. Lawler, III (Ed.), Advances in group processes, vol. 2: 77-121. Greenwich, CT: JAI Press.

Van der Walt, N., Ingley, C., Shergill, G., \& Townsend, A. 2006. Board configuration: Are diverse boards better boards? Corporate Governance, 6:129-147.

van Knippenberg, D., De Dreu, C. K. W., \& Homan, A. C. 2004. Work group diversity and group performance: An integrative model and research agenda. Journal of Applied Psychology, 89: 1008-1022.

van Knippenberg, D., \& Schippers, M. C. 2007. Workgroup diversity. Annual Review of Psychology, 58: 515541.

Venkatraman, N., \& Ramanujam, V. 1986. Measurement of business performance in strategy research: A comparison of approaches. Academy of Management Review, 11: 801-814.

Weinzimmer, L. G., Nystrom, P. C., \& Freeman, S. J. 1998. Measuring organizational growth: Issues, consequences, and guidelines. Journal of Management, 24: 235-262.

West, C. T., \& Schwenk, C. R. 1996. Top management team strategic consensus, demographic homogeneity and firm performance: A report of resounding nonfindings. Strategic Management Journal, 17: 571.

Williams, K. Y., \& O’Reilly, C. A. 1998. Demography and diversity in organizations: A review of 40 years of research. Research in Organizational Behavior, 20: 77-140. 
Winter, S. G. 2003. Understanding dynamic capabilities. Strategic Management Journal, 24 : 991-995.

Zaheer, A., \&Zaheer, S. 1997. Catching the wave: Alertness, responsiveness, and market influence in global electronic networks. Management Science, 43: 809-825.

Zollo, M., \& Winter, S. G. 2002. Deliberate learning and the evolution of dynamic capabilities. Organization Science, 13: 339-351. 
Table 1. Summary of key findings by level of analysis.

\begin{tabular}{|c|c|}
\hline Study & Key Findings \\
\hline \multicolumn{2}{|c|}{ Board of directors } \\
\hline Bonn (2004) & $\begin{array}{l}\text { - The proportion of female directors is positive related to } \\
\text { firm performance (i.e., market-to-book ratio) }\end{array}$ \\
\hline Campbell and M'inguez-Vera (2008) & $\begin{array}{l}\text { - Gender diversity (i.e., percent of women) positively } \\
\text { affects firm value, although the opposite causal } \\
\text { relationship is not significant }\end{array}$ \\
\hline \multirow[t]{2}{*}{ Campbell and M'inguez-Vera (2010) } & $\begin{array}{l}\text { - The announcement of female board appointments is } \\
\text { related to positive stock market reaction (i.e., abnormal } \\
\text { returns) }\end{array}$ \\
\hline & $\begin{array}{l}\text { - Gender diversity (i.e., percent of women) positively } \\
\text { affects firm value }\end{array}$ \\
\hline \multirow[t]{2}{*}{$\begin{array}{l}\text { Carter, D’Souza, Simkins, and Simpson } \\
(2010)\end{array}$} & $\begin{array}{l}\text { - Gender diversity on boards and board committees are } \\
\text { positively related to firm performance, but not to firm } \\
\text { value }\end{array}$ \\
\hline & $\begin{array}{l}\text { The above results only hold in fixed-effect regression } \\
\text { equations, thus suggesting endogeneity }\end{array}$ \\
\hline Carter, Simkins, and Simpson (2003) & $\begin{array}{l}\text { Diversity, in terms of the presence and percentage of } \\
\text { women or minorities, is positively related to firm value }\end{array}$ \\
\hline Erhardt, Werbel, and Shrader (2003) & $\begin{array}{l}\text { Diversity, in terms of the percentage of female and } \\
\text { minority directors, is positively related to firm } \\
\text { performance }\end{array}$ \\
\hline McIntyre, Murphy, and Mitchell (2007) & $\begin{array}{l}\text { - Age and tenure diversity are related to firm value (i.e., } \\
\text { Tobin's Q), such that low and high levels of diversity are } \\
\text { associated with lower performance while moderate levels } \\
\text { of diversity are associated with higher performance }\end{array}$ \\
\hline Rose (2007) & $\begin{array}{l}\text { - Gender, functional, and national diversity are not } \\
\text { significantly related to firm value }\end{array}$ \\
\hline \multirow[t]{2}{*}{ Siciliano (1996) } & $\begin{array}{l}\text { Occupational diversity is positively related to firm } \\
\text { performance, while age diversity is positively related to } \\
\text { level of donations }\end{array}$ \\
\hline & $\begin{array}{l}\text { - Gender diversity is positively related to performance as } \\
\text { mission fulfillment, but negatively related to performance } \\
\text { as level of donations }\end{array}$ \\
\hline \multirow[t]{2}{*}{ Smith, Smith, and Verner (2006) } & $\begin{array}{l}\text { Board gender diversity is positively related to firm } \\
\text { performance as contribution margin, whereas CEO } \\
\text { gender diversity relates to performance as gross profit } \\
\text { margin }\end{array}$ \\
\hline & $\begin{array}{l}\text { - On boards, female nonstaff members have a lower effect } \\
\text { on firm performance than do staff members }\end{array}$ \\
\hline $\begin{array}{l}\text { Van der Walt, Ingley, Shergill, and Townsend } \\
\text { (2006) }\end{array}$ & $\begin{array}{l}\text { - Among firms with high strategic complexity, those with } \\
\text { low diversity perform better than those with high } \\
\text { diversity }\end{array}$ \\
\hline
\end{tabular}

\section{TMT}

Boone and Hendriks (2009)

- Functional background diversity increases firm performance when collaborative behavior, accurate information exchange, and decision-making decentralization are high

- Locus of control diversity decreases firm performance 
Buyl, Boone, Hendriks, and Matthyssens (2011)

Carpenter (2002)

Certo et al. (2006)

Goll, Sambharya, and Tucci (2001)

Keck (1997)

Kilduff, Angelmar, and Mehra (2000)

Li-Qun, Chung-Ming, Young, and Wang (2005)

Murray (1989)

Olson, Parayitam, and Twigg (2006)

Pegels, Song, and Baik (2000) only when decision-making decentralization is high

- The relationship between functional diversity and firm performance is stronger when the CEO is not the founder of the firm but has high tenure overlap with TMT members

- The moderating effect of CEO as founder is mediated by the interaction of functional diversity and information exchange and integration

- The positive relationship between educational diversity and firm performance is stronger in firms with high levels of internationalization, whereas the positive effects of background and tenure diversity are weaker in firms with high levels of internationalization

- The complexity-contingent relationships between educational, background, and tenure diversity and firm performance is strongest in short-tenured teams

- Diversity, in terms of functional and tenure diversity, is positively related to firm performance (i.e., ROA)

- Potential moderating influences on the above results include strategic variables (i.e., diversification, R\&D expenditures, internationalization) and TMT operationalizations

- Age, tenure, education, and functional background diversity are positively related to progressive decisionmaking

- Age and education diversity are positively related to firm performance

- Functional diversity is positively related to firm performance in turbulent contexts

- Team tenure diversity is positively related to firm performance in stable contexts and negatively related to performance in turbulent contexts, while there is a positive association in the microcomputer industry regardless of environmental context

- Age diversity is positively related to firm performance

- Cognitive diversity (i.e., interpretive ambiguity) is positively related to firm performance, but there is a reciprocal effect of such performance changes on cognitive diversity such that ambiguity is reduced

- Average age is positively related to firm performance (i.e., ROA and ROE)

- Education and career experience diversity is negatively related to firm performance, while occupational experience diversity is positively related to performance

- $\quad$ Temporal and occupational diversity are positively related to short- and long-term performance, especially in the oil industry

- $\quad$ Functional diversity is positively related to strategic choice (i.e., M\&A and innovation), whereas age diversity is negatively related to strategic choice

- The positive relationship between functional diversity and firm performance is mediated by strategic choice

- Educational and functional diversity is negatively related to firm performance, such that airlines that deviate from the dominant characteristics of their competitive 
Ren and Wang (2011)

Richard and Shelor (2002)

Roberson and Park (2007)

Simons, Pelled, and Smith (1999)

West and Schwenk (1996)

Dwyer, Richard, and Chadwick (2003)

Pitts and Jarry (2007)

Richard, Barnett, Dwyer, and Chadwick (2004)

Shrader, Blackburn, and Iles (1997) interaction groups have lower future profitability potential

- Gender diversity is positively related to firm value, especially when female TMT members have high human capital (i.e., average education level) or social capital (i.e., social and political connections)

- Age diversity has both a positive linear and curvilinear, inverted U-shaped relationship with firm performance (i.e., sales growth)

- The relationship between age diversity and firm performance as sales growth is moderated by environmental complexity, innovation, and decentralization, whereas the relationship with performance as ROA is moderated only by decentralization

- Leader racial diversity has a curvilinear, U-shaped relationship to firm performance (e.g., book-to-market), such that performance declines with increases in diversity up to approximately $22 \%$, beyond which further increases are associated with improved performance

- $\quad$ Education level diversity and PEU diversity each interacts with debate to affect firm performance, such that performance is higher in firms with greater diversity and higher levels of debate

- The results are partially mediated by decision comprehensiveness

- Diversity is not significantly related to firm performance

\section{Managers}

- Racial diversity is positively related to firm performance, which is mediated by competitive intensity (i.e., initiating more competitive actions and more competitive action variety), especially in high-growth environments

- Gender diversity is positively related to performance (i.e., productivity) in firms with a stronger growth orientation or clan organizational culture, whereas it is negatively related to performance (i.e., ROE) in firms with a stronger adhocracy culture

- Manager ethnic diversity is not significantly related to school performance, although teacher diversity is negatively related

- The relationship between racial diversity and firm performance is moderated by innovativeness, such that low and high levels of diversity are associated with higher performance than are moderate levels of diversity in firms with highly innovative strategic postures

- The relationship between gender diversity and firm performance (i.e., productivity) is moderated by risk taking, such that low and high levels of diversity are associated with lower performance than are moderate levels of diversity in high risk-taking firms

- Gender diversity is positively related to firm performance, whereas diversity on TMTs and boards is not significantly related to performance 


\section{Employees}

Frink et al. (2003)

wholesale

Gonzalez and DeNisi (2009)

Hartenian and Gudmundson (2000)

Herring (2009)

Kunze, Boehm, and Bruch (2011)

Leonard, Levine, and Joshi (2004)

Li et al. (2011)

Richard (2000)

Richard, Ford, and Ismail (2006)
- Gender diversity is related to perceived market performance, such that it increases with greater diversity up to $50 \%$ female representation and decreases with further increases in diversity

- For performance (i.e., EBIT) in the service

- retail industry sector, the inflection point is $56 \%$

- $\quad$ ethnic diversity is associated with higher firm performance (i.e., productivity and return on income) is positive under conditions of a supportive diversity climate, but negative under adverse climate conditions

- Gender diversity and performance (i.e., productivity and return on profit) have an inverse U-shaped association under conditions of a supportive diversity climate and a U-shaped association under adverse climate condition

- Racial diversity is positively associated with firm performance, although the results do not hold across multiple years

- Gender diversity is positively related to perceived sales, number of customers, and profitability, whereas racial diversity is positively related to sales, number of customers, and market share, after accounting for other explanatory variables

- Age diversity is negatively related to firm performance through the mediating effects of perceived age discrimination climate and collective affective commitment

- The effects of racial diversity on firm performance varies based on the category examined (e.g.,\% of Asians in the surrounding community is positively related, \%of black employees is negatively related,\% of Hispanic employees is dependent on store location in communities where a subset of potential customers is Hispanic)

- Gender (i.e., \%of female employees) and age (i.e.,\% of older employees) diversity are negatively related to firm performance

- Age diversity is positively related to firm performance (i.e., ROA) when geographic market diversification is high

- The effects of age diversity are stronger for firms from Western societies than those from East Asian societies

- Racial diversity interacts with business strategy to affect firm performance, such that diverse firms with a growth strategy experience higher performance than those with a no-growth strategy or a downsizing strategy, the latter of which has the lowest productivity gains

- Gender and racial diversity interacts with organizational life cycle to affect firm performance, such that diversity enhances performance in banks at earlier stages of development than in those at later stages of development

- Gender diversity interacts with organizational structure to affect firm performance (i.e., ROA), such that diversity enhances performance in banks with a narrow span of control than in those with a broad span of control 
Richard, McMillan, Chadwick, and Dwyer (2003)

Richard, Murthi, and Ismail (2007)
- Racial diversity interacts with innovation strategy to affect firm performance, such that diversity enhances performance in banks pursuing an innovation strategy and reduces performance in those with a lower degree of innovativeness

- Racial diversity has a curvilinear, U-shaped relationship with short-term performance (i.e., productivity), although the relationship is stronger in service rather than manufacturing firms and in firms operating in more stable rather than volatile environments

- Racial diversity has a positive, linear relationship with long-term performance (i.e., Tobin'sQ), although the relationship is stronger inmunificent environments 
Table 2. Summary of the study of diversity and firm performance by level of analysis

\begin{tabular}{|c|c|c|c|c|c|}
\hline Study & Diversity Type & Outcomes & Theory & Mediators & Moderators \\
\hline \multicolumn{6}{|c|}{ Board of Directors } \\
\hline Bonn (2004) & $\begin{array}{l}\text { Outsider, } \\
\text { gender, age }\end{array}$ & $\begin{array}{l}\text { Market-to- } \\
\text { book value, } \\
\text { ROE }\end{array}$ & $\begin{array}{l}\text { Stewardship } \\
\text { theory }\end{array}$ & & \\
\hline $\begin{array}{l}\text { Campbell and } \\
\text { M'inguez- } \\
\text { Vera (2008) }\end{array}$ & Gender & Tobin's Q & $\begin{array}{l}\text { Value-in- } \\
\text { diversity, } \\
\text { social } \\
\text { psychology }\end{array}$ & & \\
\hline $\begin{array}{l}\text { Campbell and } \\
\text { M'inguez- } \\
\text { Vera (2010) }\end{array}$ & Gender & Tobin's Q & $\begin{array}{l}\text { Value-in- } \\
\text { diversity, } \\
\text { social } \\
\text { psychology }\end{array}$ & & \\
\hline $\begin{array}{l}\text { Carter et al. } \\
(2010)\end{array}$ & Gender, race & $\begin{array}{l}\text { Tobin's Q, } \\
\text { ROA }\end{array}$ & $\begin{array}{l}\text { Resource } \\
\text { dependence, } \\
\text { human } \\
\text { capital, } \\
\text { agency, social } \\
\text { psychology }\end{array}$ & & \\
\hline $\begin{array}{l}\text { Carter et al. } \\
\text { (2003) }\end{array}$ & Gender, race & Tobin's Q & $\begin{array}{l}\text { Value-in- } \\
\text { diversity, } \\
\text { agency }\end{array}$ & & \\
\hline $\begin{array}{l}\text { Erhardt et al. } \\
\text { (2003) }\end{array}$ & Gender, race & ROI, ROA & $\begin{array}{l}\text { Value-in } \\
\text { diversity, } \\
\text { social } \\
\text { psychology, } \\
\text { upper } \\
\text { echelons }\end{array}$ & & \\
\hline $\begin{array}{l}\text { McIntyre et al. } \\
\text { (2007) }\end{array}$ & Tenure, age & $\begin{array}{l}\text { Tobin's Q, } \\
\text { EVA, ROA }\end{array}$ & $\begin{array}{l}\text { Agency theory, } \\
\text { group } \\
\text { dynamics }\end{array}$ & & \\
\hline Rose (2007) & $\begin{array}{l}\text { Gender, } \\
\text { educational } \\
\text { background, } \\
\text { citizenship }\end{array}$ & Tobin’s Q & $\begin{array}{l}\text { Organizational } \\
\text { control }\end{array}$ & & \\
\hline $\begin{array}{c}\text { Siciliano } \\
(1996)\end{array}$ & $\begin{array}{l}\text { Gender, age, } \\
\text { occupation }\end{array}$ & $\begin{array}{l}\text { Social } \\
\text { performance, } \\
\text { efficiency } \\
\text { (i.e., } \\
\text { revenues-to- } \\
\text { expenses), } \\
\text { donations }\end{array}$ & $\begin{array}{l}\text { Resource } \\
\text { dependence }\end{array}$ & & \\
\hline $\begin{array}{l}\text { Smith et } \\
\text { al.(2006) }\end{array}$ & Gender & $\begin{array}{l}\text { Gross profit- } \\
\text { to-sales, } \\
\text { contribution } \\
\text { margin-to- } \\
\text { sales, } \\
\text { operating } \\
\text { income-to- } \\
\text { sales, net } \\
\text { income after } \\
\text { tax-to-sales }\end{array}$ & $\begin{array}{l}\text { Value-in- } \\
\text { diversity, } \\
\text { information } \\
\text { elaboration }\end{array}$ & & \\
\hline
\end{tabular}




\begin{tabular}{|c|c|c|c|c|c|}
\hline $\begin{array}{l}\text { Van der Walt } \\
\text { et al. (2006) }\end{array}$ & $\begin{array}{l}\text { Gender, race, } \\
\text { age }\end{array}$ & $\begin{array}{l}\text { ROA, ROE, } \\
\text { sales growth, } \\
\text { total net asset } \\
\text { growth, cash } \\
\text { flow return } \\
\text { on total assets }\end{array}$ & $\begin{array}{l}\text { Value-in- } \\
\text { diversity, } \\
\text { information } \\
\text { elaboration, } \\
\text { corporate } \\
\text { governance }\end{array}$ & & $\begin{array}{l}\text { Strategic } \\
\text { complexity }\end{array}$ \\
\hline \multicolumn{6}{|c|}{ TMT } \\
\hline $\begin{array}{l}\text { Boone and } \\
\text { Hendriks } \\
(2009)\end{array}$ & $\begin{array}{l}\text { Functional } \\
\text { background, } \\
\text { locus of } \\
\text { control }\end{array}$ & ROS, ROA & $\begin{array}{l}\text { Upper } \\
\text { echelons, } \\
\text { information } \\
\text { elaboration }\end{array}$ & & $\begin{array}{l}\text { Collaborative } \\
\text { behavior, accurate } \\
\text { info exchange, } \\
\text { decentralized } \\
\text { decision-making }\end{array}$ \\
\hline $\begin{array}{l}\text { Buyl et al. } \\
\text { (2011) }\end{array}$ & $\begin{array}{l}\text { Functional } \\
\text { background }\end{array}$ & ROS & $\begin{array}{l}\text { Upper echelon, } \\
\text { information } \\
\text { elaboration }\end{array}$ & $\begin{array}{l}\text { Information } \\
\text { exchange and } \\
\text { integration }\end{array}$ & $\begin{array}{l}\text { CEO characteristics } \\
\text { (functional } \\
\text { background, } \\
\text { status as founder, } \\
\text { shared experience } \\
\text { with TMT) }\end{array}$ \\
\hline $\begin{array}{l}\text { Carpenter } \\
\text { (2002) }\end{array}$ & $\begin{array}{l}\text { Education, } \\
\text { functional } \\
\text { background, } \\
\text { tenure }\end{array}$ & ROA & Upper echelons & & $\begin{array}{l}\text { Internationalization, } \\
\text { TMT average } \\
\text { tenure }\end{array}$ \\
\hline $\begin{array}{l}\text { Certo et al. } \\
\text { (2006) }\end{array}$ & $\begin{array}{l}\text { Organizational } \\
\text { and position } \\
\text { tenure, } \\
\text { functional } \\
\text { background, } \\
\text { education }\end{array}$ & $\begin{array}{l}\text { ROA (1-year, } \\
\text { 3-year and } \\
\text { growth), } \\
\text { ROE (3- } \\
\text { year), sales } \\
\text { growth }\end{array}$ & $\begin{array}{l}\text { Upper } \\
\text { echelons, } \\
\text { information } \\
\text { elaboration }\end{array}$ & & \\
\hline $\begin{array}{l}\text { Goll et al. } \\
\text { (2001) }\end{array}$ & $\begin{array}{l}\text { Age, tenure, } \\
\text { education, } \\
\text { functional } \\
\text { background }\end{array}$ & $\begin{array}{l}\text { ROA, ROI, } \\
\text { ROE, EPS }\end{array}$ & Upper echelons & & \\
\hline Keck (1997) & $\begin{array}{l}\text { Functional } \\
\text { background, } \\
\text { tenure }\end{array}$ & ROA & $\begin{array}{l}\text { Group theory } \\
\text { (i.e., task and } \\
\text { maintenance } \\
\text { functions) }\end{array}$ & & \\
\hline $\begin{array}{l}\text { Kilduff et al. } \\
\text { (2000) }\end{array}$ & $\begin{array}{l}\text { Cognitive, } \\
\text { nationality, } \\
\text { function, age }\end{array}$ & $\begin{array}{l}\text { Market share, } \\
\text { profitability } \\
\text { (simulated) }\end{array}$ & $\begin{array}{l}\text { Upper } \\
\text { echelons, } \\
\text { social } \\
\text { information } \\
\text { processing }\end{array}$ & & \\
\hline $\begin{array}{l}\text { Li-Qun et } \\
\text { al.(2005) }\end{array}$ & $\begin{array}{l}\text { Age, education, } \\
\text { occupational } \\
\text { field, career } \\
\text { experience }\end{array}$ & ROA, ROE & $\begin{array}{l}\text { Relational } \\
\text { demography, } \\
\text { upper } \\
\text { echelons }\end{array}$ & & \\
\hline Murray (1989) & $\begin{array}{l}\text { Age, firm } \\
\text { tenure, team } \\
\text { tenure, } \\
\text { occupational } \\
\text { background, } \\
\text { education }\end{array}$ & $\begin{array}{l}\text { Earnings-to- } \\
\text { sales, } \\
\text { earnings-to- } \\
\text { total capital, } \\
\text { earnings-to- } \\
\text { net worth, } \\
\text { and earnings- } \\
\text { to-equity; } \\
\text { stock price- } \\
\text { to- earnings, }\end{array}$ & $\begin{array}{l}\text { Organizational } \\
\text { control }\end{array}$ & & $\begin{array}{l}\text { Competition, } \\
\text { change }\end{array}$ \\
\hline
\end{tabular}




\begin{tabular}{|c|c|c|c|c|c|}
\hline & & $\begin{array}{l}\text { stock price- } \\
\text { to-book value }\end{array}$ & & & \\
\hline $\begin{array}{l}\text { Olson et al. } \\
\text { (2006) }\end{array}$ & $\begin{array}{l}\text { Functional } \\
\text { background, } \\
\text { age }\end{array}$ & ROA & $\begin{array}{l}\text { Value-in- } \\
\text { diversity }\end{array}$ & $\begin{array}{l}\text { M\&A activity, } \\
\text { R\&D intensity }\end{array}$ & \\
\hline $\begin{array}{l}\text { Pegels et al. } \\
(2000)\end{array}$ & $\begin{array}{l}\text { Function, age, } \\
\text { education, } \\
\text { company } \\
\text { tenure, }\end{array}$ & Load factors & $\begin{array}{l}\text { Strategic group, } \\
\text { strategic } \\
\text { choice, upper } \\
\text { echelons }\end{array}$ & & $\begin{array}{l}\text { Competitive } \\
\text { interaction group }\end{array}$ \\
\hline $\begin{array}{l}\text { Ren and Wang } \\
\text { (2011) }\end{array}$ & Gender & Tobin's Q & $\begin{array}{l}\text { Resource } \\
\text { dependence }\end{array}$ & & $\begin{array}{l}\text { Human capital, } \\
\text { social capital }\end{array}$ \\
\hline $\begin{array}{l}\text { Richard and } \\
\text { Shelor } \\
(2002)\end{array}$ & Age & $\begin{array}{l}\text { ROA, } \\
\text { percentage } \\
\text { change in } \\
\text { sales }\end{array}$ & $\begin{array}{l}\text { Social } \\
\text { psychology, } \\
\text { information } \\
\text { elaboration, } \\
\text { contingency }\end{array}$ & & $\begin{array}{l}\text { Centralization, } \\
\text { R\&D intensity, } \\
\text { environmental } \\
\text { complexity }\end{array}$ \\
\hline $\begin{array}{r}\text { Roberson and } \\
\text { Park (2007) }\end{array}$ & Race & $\begin{array}{l}\text { Revenues, net } \\
\text { income, } \\
\text { book-to- } \\
\text { market value } \\
\text { of common } \\
\text { equity }\end{array}$ & $\begin{array}{l}\text { Upper } \\
\text { echelons, } \\
\text { information } \\
\text { elaboration }\end{array}$ & & \\
\hline $\begin{array}{l}\text { Simons et al. } \\
\text { (1999) }\end{array}$ & $\begin{array}{l}\text { Functional } \\
\text { background, } \\
\text { education, } \\
\text { tenure, age, } \\
\text { PEU }\end{array}$ & $\begin{array}{l}\text { Profit-to-sales, } \\
\text { sales growth }\end{array}$ & $\begin{array}{l}\text { Information } \\
\text { elaboration }\end{array}$ & $\begin{array}{l}\text { Decision } \\
\text { comprehensivene } \\
\text { ss }\end{array}$ & \\
\hline $\begin{array}{l}\text { West and } \\
\text { Schwenk } \\
(1996)\end{array}$ & $\begin{array}{l}\text { Composite of } \\
12 \text { categories }\end{array}$ & $\begin{array}{l}\text { Net profit, } \\
\text { ROA, overall } \\
\text { perceived } \\
\text { performance }\end{array}$ & $\begin{array}{l}\text { Strategic } \\
\text { consensus }\end{array}$ & & Industry \\
\hline \multicolumn{6}{|c|}{ Managers } \\
\hline $\begin{array}{l}\text { Andrevski et } \\
\text { al. (2014) }\end{array}$ & Race & $\begin{array}{l}\text { Market share } \\
\text { gain, } \\
\text { stockholder } \\
\text { returns }\end{array}$ & $\begin{array}{l}\text { Knowledge- } \\
\text { based view }\end{array}$ & $\begin{array}{l}\text { Competitive } \\
\text { intensity }\end{array}$ & $\begin{array}{c}\text { Environmental } \\
\text { munificence }\end{array}$ \\
\hline $\begin{array}{l}\text { Dwyer et al. } \\
(2003)\end{array}$ & Gender & $\begin{array}{l}\text { Employee } \\
\text { productivity, } \\
\text { ROE }\end{array}$ & $\begin{array}{l}\text { Upper } \\
\text { echelons, } \\
\text { social } \\
\text { psychology, } \\
\text { contingency }\end{array}$ & & $\begin{array}{l}\text { Growth orientation, } \\
\text { organizational } \\
\text { culture }\end{array}$ \\
\hline $\begin{array}{l}\text { Pitts and Jarry } \\
\text { (2007) }\end{array}$ & Race & $\begin{array}{l}\text { Student pass } \\
\text { rates, SAT } \\
\text { scores, } \\
\text { dropout rates }\end{array}$ & $\begin{array}{l}\text { Social } \\
\text { psychology, } \\
\text { information } \\
\text { elaboration, } \\
\text { similarity- } \\
\text { attraction }\end{array}$ & & \\
\hline $\begin{array}{l}\text { Richard et al. } \\
\text { (2004) }\end{array}$ & Gender, race & $\begin{array}{l}\text { Employee } \\
\text { productivity, } \\
\text { ROE }\end{array}$ & $\begin{array}{l}\text { Value-in- } \\
\text { diversity }\end{array}$ & & $\begin{array}{l}\text { Entrepreneurial } \\
\text { orientation, risk } \\
\text { taking, } \\
\text { innovativeness }\end{array}$ \\
\hline
\end{tabular}




\begin{tabular}{|c|c|c|c|c|c|}
\hline $\begin{array}{l}\text { Shrader et al. } \\
\text { (1997) }\end{array}$ & Gender & $\begin{array}{l}\text { ROA, ROI, } \\
\text { ROE, ROS }\end{array}$ & RBV & & \\
\hline \multicolumn{6}{|c|}{ Employees } \\
\hline $\begin{array}{l}\text { Frink et al. } \\
\text { (2003) }\end{array}$ & Gender & $\begin{array}{l}\text { Perceived } \\
\text { market } \\
\text { performance, } \\
\text { employee } \\
\text { productivity, } \\
\text { EBIT }\end{array}$ & $\begin{array}{c}\text { Organizational } \\
\text { demography }\end{array}$ & & \\
\hline $\begin{array}{l}\text { Gonzalez and } \\
\text { DeNisi } \\
(2009)\end{array}$ & Gender, race & $\begin{array}{l}\text { Employee } \\
\text { productivity, } \\
\text { return on } \\
\text { profit; return } \\
\text { on income }\end{array}$ & $\mathrm{RBV}$ & & Diversity climate \\
\hline $\begin{array}{l}\text { Hartenian and } \\
\text { Gudmundson } \\
(2000)\end{array}$ & Race & $\begin{array}{l}\text { Revenue, net } \\
\text { income }\end{array}$ & $\begin{array}{l}\text { Value-in- } \\
\text { diversity }\end{array}$ & & \\
\hline Herring (2009) & Gender, race & $\begin{array}{l}\text { Sales, number } \\
\text { of customers, } \\
\text { perceived } \\
\text { market share } \\
\text { and relative } \\
\text { profitability }\end{array}$ & $\begin{array}{l}\text { Value-in- } \\
\text { diversity, } \\
\text { "diversity as } \\
\text { process loss," } \\
\text { institutional } \\
\text { theory }\end{array}$ & & $\begin{array}{l}\text { Organization } \\
\text { characteristics } \\
\text { (legal form, size, } \\
\text { age), industry, } \\
\text { region }\end{array}$ \\
\hline $\begin{array}{l}\text { Kunze et al. } \\
\text { (2011) }\end{array}$ & Age & $\begin{array}{l}\text { Composite of } \\
\text { operational } \\
\text { and } \\
\text { organizationa } \\
\text { l performance }\end{array}$ & $\begin{array}{l}\text { Social } \\
\text { psychology, } \\
\text { career } \\
\text { timetables, } \\
\text { prototype } \\
\text { similarity }\end{array}$ & $\begin{array}{l}\text { Perceived age } \\
\text { discrimination } \\
\text { climate, affective } \\
\text { commitment }\end{array}$ & \\
\hline $\begin{array}{l}\text { Leonard et al. } \\
\text { (2004) }\end{array}$ & $\begin{array}{l}\text { Gender, race, } \\
\text { age }\end{array}$ & $\begin{array}{l}\text { Average real } \\
\text { monthly sales } \\
\text { per store }\end{array}$ & $\begin{array}{l}\text { Social } \\
\text { psychology, } \\
\text { similarity- } \\
\text { attraction, } \\
\text { Becker's } \\
\text { theory of } \\
\text { customer } \\
\text { discriminatio } \\
\text { n }\end{array}$ & & \\
\hline Li et al. (2011) & Age & $\begin{array}{l}\text { ROA, } \\
\text { employee } \\
\text { productivity }\end{array}$ & $\begin{array}{l}\text { Value-in- } \\
\text { diversity, } \\
\text { RBV of the } \\
\text { firm }\end{array}$ & & $\begin{array}{l}\text { Geographic market } \\
\text { diversification, } \\
\text { firm country of } \\
\text { origin }\end{array}$ \\
\hline Richard (2000) & Race & $\begin{array}{l}\text { Employee } \\
\text { productivity, } \\
\text { ROE, } \\
\text { perceived } \\
\text { market } \\
\text { performance }\end{array}$ & $\begin{array}{l}\text { Value-in- } \\
\text { diversity, } \\
\text { RBV of the } \\
\text { firm, } \\
\text { contingency }\end{array}$ & & Growth strategy \\
\hline $\begin{array}{l}\text { Richard et al. } \\
(2006)\end{array}$ & Gender, race & $\begin{array}{l}\text { Employee } \\
\text { productivity, } \\
\text { ROE, ROA }\end{array}$ & $\begin{array}{l}\text { Information } \\
\text { elaboration, } \\
\text { contingency }\end{array}$ & & $\begin{array}{l}\text { Organizational } \\
\text { structure, } \\
\text { lifecycle stage }\end{array}$ \\
\hline $\begin{array}{l}\text { Richard et al. } \\
(2003)\end{array}$ & Race & ROE & $\begin{array}{l}\text { Social } \\
\text { psychology, } \\
\text { RBV of the } \\
\text { firm, }\end{array}$ & & Innovation strategy \\
\hline
\end{tabular}


Richard et al. Race (2007)
Employee Information

productivity, elaboration,

Tobin's Q social contact,

contingency
Industrial sector, munificence, environmental instability 


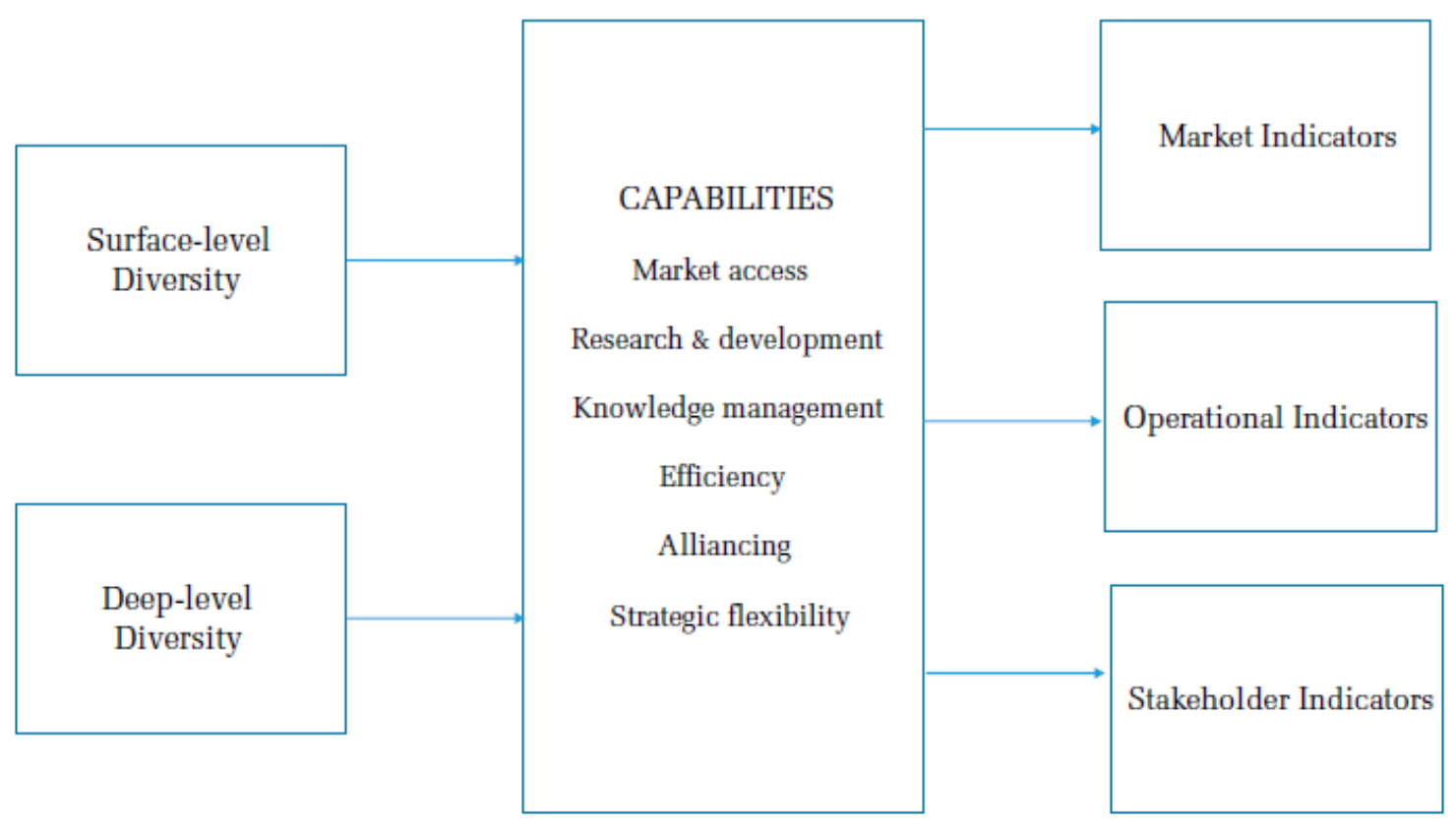

Figure 1. A dynamic capabilities approach to the study of diversity and firm performance. 